EEG-71

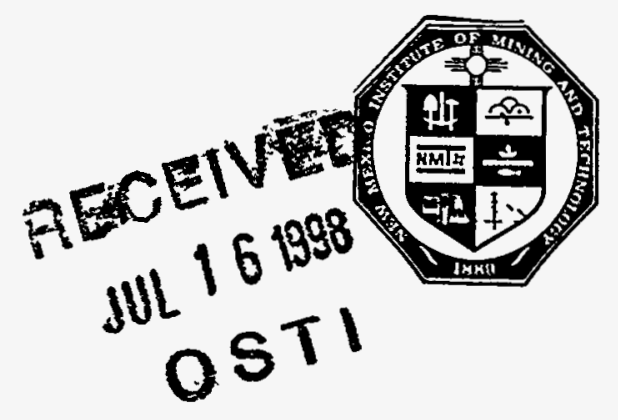

MINE STABILITY EVALUATION OF PANEL 1 DURING WASTE EMPLACEMENT OPERATIONS AT WIPP

Hamid Maleki, Ph.D., P.E.

Maleki Technologies, Inc.

Environmental Evaluation Group

New Mexico

July 1998 


\section{MINE STABILITY EVALUATION OF PANEL 1 DURING WASTE EMPLACEMENT OPERATIONS AT WIPP}

Hamid Maleki, Ph.D., P.E.

Maleki Technologies, Inc.

Environmental Evaluation Group 7007 Wyoming Blvd., NE, Suite F-2 Albuquerque, New Mexico 87109

and

505 North Main Street, P.O. Box 3149

Carlsbad, New Mexico 88221-3149

July 1998 


\section{FOREWORD}

The purpose of the New Mexico Environmental Evaluation Group (EEG) is to conduct an independent technical evaluation of the Waste Isolation Pilot Plant (WIPP) Project to ensure the protection of the public health and safety and the environment. The WIPP Project, located in southeastern New Mexico, is being constructed as a repository for the disposal of transuranic (TRU) radioactive wastes generated by the national defense programs. The EEG was established in 1978 with funds provided by the U.S. Department of Energy (DOE) to the State of New Mexico. Public law 100-456, the National Defense Authorization Act, Fiscal Year 1989, Section 1433, assigned EEG to the New Mexico Institute of Mining and Technology and continued the original contract DEAC04-79AL10752 through DOE contract DE-AC04-89AL58309. The National Defense Authorization Act for Fiscal Year 1994, Public Law 103-160, continues the authorization.

EEG performs independent technical analyses of the suitability of the proposed site; the design of the repository, its planned operation, and its long-term integrity; suitability and safety of the transportation systems; suitability of the Waste Acceptance Criteria and the generator sites' compliance with them; and related subjects. These analyses include assessments of reports issued by the DOE and its contractors, other federal agencies and organizations, as they relate to the potential health, safety and environmental impacts from WIPP. Another important function of EEG is the independent environmental monitoring of background radioactivity in air, water, and soil, both on-site and off-site.

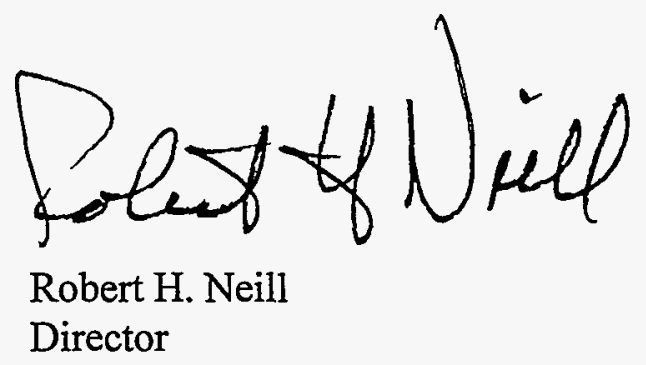




\section{EEG STAFF}

Sally C. Ballard, B.S., Radiochemist

William T. Bartlett, Ph.D., Health Physicist

Radene Bradley, Secretary III

James K. Channell, Ph.D., Environmental Engineer/Health Physicist

Lokesh Chaturvedi, Ph.D., Deputy Director \& Engineering Geologist

Patricia D. Fairchild, Secretary III

Donald H. Gray, M.A., Environmental Specialist

Jim W. Kenney, M.S., Environmental Scientist/Supervisor

Lanny King, Assistant Environmental Technician

Robert H. Neill, M.S., Director

Dale F. Rucker, M.S., Performance Assessment Engineer

Jill Shortencarier, Executive Assistant

Matthew K. Silva, Ph.D., Chemical Engineer

Susan Stokum, Administrative Secretary

Ben A. Walker, B.A., Quality Assurance Specialist

Brenda J. West, B.A., Administrative Officer 


\section{PREFACE}

(By Lokesh Chaturvedi)

The Waste Isolation Pilot Plant (WIPP) Land Withdrawal Act (Public Law 102-579, and as amended by Public Law 104-201) requires an annual evaluation of the mine safety of WIPP to be conducted by the U.S. Bureau of Mines (USBM). Such evaluations were conducted by the USBM in 1993, 1994, and 1995. After the abolition of the USBM in 1995, the U.S. Department of Energy (DOE) did not pursue independent outside annual evaluations and has informed the Environmental Evaluation Group (EEG) that "The CAO sees no value in continuing the type of independent evaluation performed by the U.S. Bureau of Mines"1. The EEG decided to fill this gap by inviting Dr. Hamid Maleki, who had conducted the WIPP annual evaluations as a mining engineer with the USBM and is now the Principal of Maleki Technologies, Inc., to conduct an annual evaluation in 1996 as an EEG consultant. His report was published as an EEG report, Stability Evaluation of the Panel 1 Rooms and the E140 Drift at WIPP, EEG-63, in August, 1996. The current report is a continuation of the work performed by Dr. Maleki in 1996 and provides his up-to-date evaluation of the stability of the Panel 1 rooms during the waste emplacement operations planned by the DOE to begin in the Summer of 1998.

The EEG provided to Dr. Maleki an estimate of 4 to 7 years as the time to fill Panel 1 rooms with contact-handled transuranic (CH-TRU) waste, without considering the impact of placing the remotehandled (RH-TRU) waste scheduled to begin in 2002. This estimate was based on the following basis (excerpts from an April 21, 1998 letter from L. Chaturvedi to H. Maleki):

With respect to the waste emplacement schedule, as you heard yourself in Carlsbad, there are so many uncertainties and potential pitfalls that only very approximate guesses can be provided. With the help of my colleague Dr. Channell, I suggest assuming 4 years and 7 years as the two alternate schedules for filling Panel 1 , for your analysis, for reasons explained below.

\footnotetext{
${ }^{1}$ Attachment to June 24, 1998 letter from E. K. Hunter, Assistant Manager, CAO/DOE to R. H. Neill, Director, EEG.
} 
The National TRU Waste Management Plan (NTWMP), Table 5-1, lists the number of shipments expected at WIPP from FY 1998 through FY 2006. These shipments are expected to average only $7.19 \mathrm{~m}^{3}$ of waste compared to a volume of $8.74 \mathrm{~m}^{3}$ for a full load of 42 drums.

Since there are 10 panels in the repository (two of them in the N-S access drifts), and the total CH-TRU waste capacity of the repository is $168,500 \mathrm{~m}^{3}$, each panel will have about $17,000 \mathrm{~m}^{3}$ of waste. Thus, 2,364 shipments are required to fill a panel, including the drifts north and south of the rooms. The shipments in Table 5-1 total 2011 through the end of FY 2001. Planned shipments for FY 2002 are 695. The last 353 shipments would occur through half the fiscal year. Thus, the DOE's management plan would have the panel 1 filled in April, 2002. The NTWMP projected emplacement rate during FY 1998 and FY 1999 would result in Room 7 being filled before the end of February, 1999 (assuming 6800 drum-equivalents per room and 2260 drum-equivalents in the 1600 drift north of Room 7).

The limitations and uncertainties not considered in this projection include the delay in RCRA certification, limitations imposed by the DOE having only 15 TRUPACTS on 5 trailer trucks at this time until more are ordered, and the delay from the anticipated lawsuits. This can easily add one year to the schedule for Room 7, and perhaps another year or two to the schedule for panel 1 as a whole.

In summary, therefore, we suggest that you assume one year for Room 7 , and 4 years for the full Panel 1 as the optimistic schedule, and 7 years for the full panel as an alternate schedule.

The EEG requested Dr. Maleki to address specific questions related to the stability of the Panel 1 rooms in his evaluation this year and what should be done to make operations in these rooms safe given the DOE decision to not abandon these rooms. Dr. Maleki's analysis shows that after a tertiary roof support system is emplaced in a room of Panel 1, the potential for roof falls is expected to be low during the first year, but will increase significantly two years after the installation of such a system. The postulated failure mechanism is the shear failure of the roof bolts due to lateral movement along Clay $\mathrm{G}$ approximately $7 \mathrm{ft}$ above the roof of the room. During the waste 
emplacement operations it will not be possible to replace the failing bolts in areas containing waste, resulting in a domino effect of failing roof bolts, which will lead to roof instability. Room \# 7 was outfitted with a tertiary roof support system in April 1998, when the one or two year clock for that room began.

Dr. Maleki recommends using the external support system, e.g. columns of timber called "cribs", in addition to the internal support system of roof bolts to be installed just before waste emplacement in a given room, to increase confidence in the stability of these rooms. He calculates that if both the internal and the external support systems are used and the rate of convergence of the roof does not accelerate, then the roof loads will most likely not be transferred to the drums during the 4 to 7 year period of waste emplacement in the panel. Using a system of external support (cribs) in the waste emplacement rooms creates operational difficulties and the DOE has made no commitment to use them. Also, it is difficult to predict when the rate of convergence may start accelerating. Acceleration did occur in two of the "Site and Preliminary Design Validation" (SPDV) rooms 7 years after excavation. The Panel 1 rooms are 10 to 12 years old, have been maintained with elaborate primary and secondary roof support systems, and have not exhibited accelerating convergence rates so far.

Dr. Maleki finds the room \#2 of Panel 1 to be the most stable room at this time, on the basis of geotechnical measurements and the least amount of visible fractures. If some waste must be brought to WIPP before a new panel of rooms can be excavated, it would seem logical to use this room rather than room \#7. Retrieval of waste from any of these rooms after emplacement would be difficult at best. To avoid any of the potential problems due to the age of Panel 1, the safest course would be to mine a fresh panel of rooms (Panel 2) for disposal. 


\section{ACKNOWLEDGMENTS}

Data for this review were provided in an efficient manner by Westinghouse geotechnical staff. In addition, Mr. J. Gilbert, Dept. of Energy, and Dr. Lokesh Chaturvedi, EEG, assisted with project coordination and planning. The cooperation of these organizations and individuals is greatly appreciated. 


\section{TABLE OF CONTENTS}

FOREWORD iii

EEG STAFF iv

PREFACE $\mathrm{v}$

ACKNOWLEDGMENTS viii

ACRONYMS $\mathrm{xi}$

1. INTRODUCTION $\ldots \ldots \ldots \ldots \ldots \ldots \ldots \ldots \ldots \ldots \ldots \ldots \ldots \ldots \ldots \ldots \ldots \ldots$

2. REVIEW OF GROUND SUPPORT EVOLUTION AT WIPP ............... 3

3. ANALYSIS OF ROOF STABILITY AND SUPPORT INTEGRITY $\ldots \ldots \ldots \ldots \ldots 6$

4. ANTICIPATED TIME FOR TRANSFERRING ROOF LOADS TO THE WASTE . 10

5. SUMMARY AND CONCLUSIONS 13

6. REFERENCES 15

FIGURES (see the List of Figures on page $\mathrm{x}$ )

ATTACHMENT A (Photographs of Roof and Rib Conditions in Panel 1)

South 1950 Access Drift

Rooms 1 to 7

South 1600 Access Drift

LIST OF EEG REPORTS 


\section{LIST OF FIGURES}

Figure 1. Location of deformation measurements over WIPP Facilities for 1998.

Figure 2. Vertical roof deformation (in) in panel 1 for 1998 review.

Figure 3. Vertical roof deformation rate (in/yr) in panel 1 for 1998 review.

Figure 4. Roof-to-floor convergence (in) in panel 1 for 1998 review.

Figure 5. Roof-to-floor convergence rate (in/yr) in panel 1 for 1998 review.

Figure 6. Compared convergence rates for 1996 and 1998 evaluations.

Figure 7. Horizontal deformation rate, (in) at clay G during $1995-1996$ period.

Figure 8. Total number of roof bolt assembly failures in Panel 1.

Figure 9a. Approximate location of threaded rebar failure in panel 1 for 1995.

Figure 9b Approximate location of threaded rebar failure in panel 1 for 1996.

Figure 9c Approximate location of threaded rebar failure in panel 1 for 1997.

Figure 9d Approximate location of threaded rebar failure in panel 1 for 1998.

Figure 10 Estimated and measured total convergence for rooms of Panel 1. 


\section{ACRONYMS}

DOE U.S. Department of Energy

EEG Environmental Evaluation Group

MTI Maleki Technologies, Inc.

RCRA Resource Conservation \& Recovery Act

SPDV Site and Preliminary Design Validation

USBM U.S. Bureau of Mines

WIPP Waste Isolation Pilot Plant 


\title{
STABILITY EVALUATION OF PANEL 1 DURING WASTE EMPLACEMENT OPERATIONS AT WIPP
}

\author{
PREPARED FOR
}

\section{ENVIRONMENTAL EVALUATION GROUP JUNE 1998}

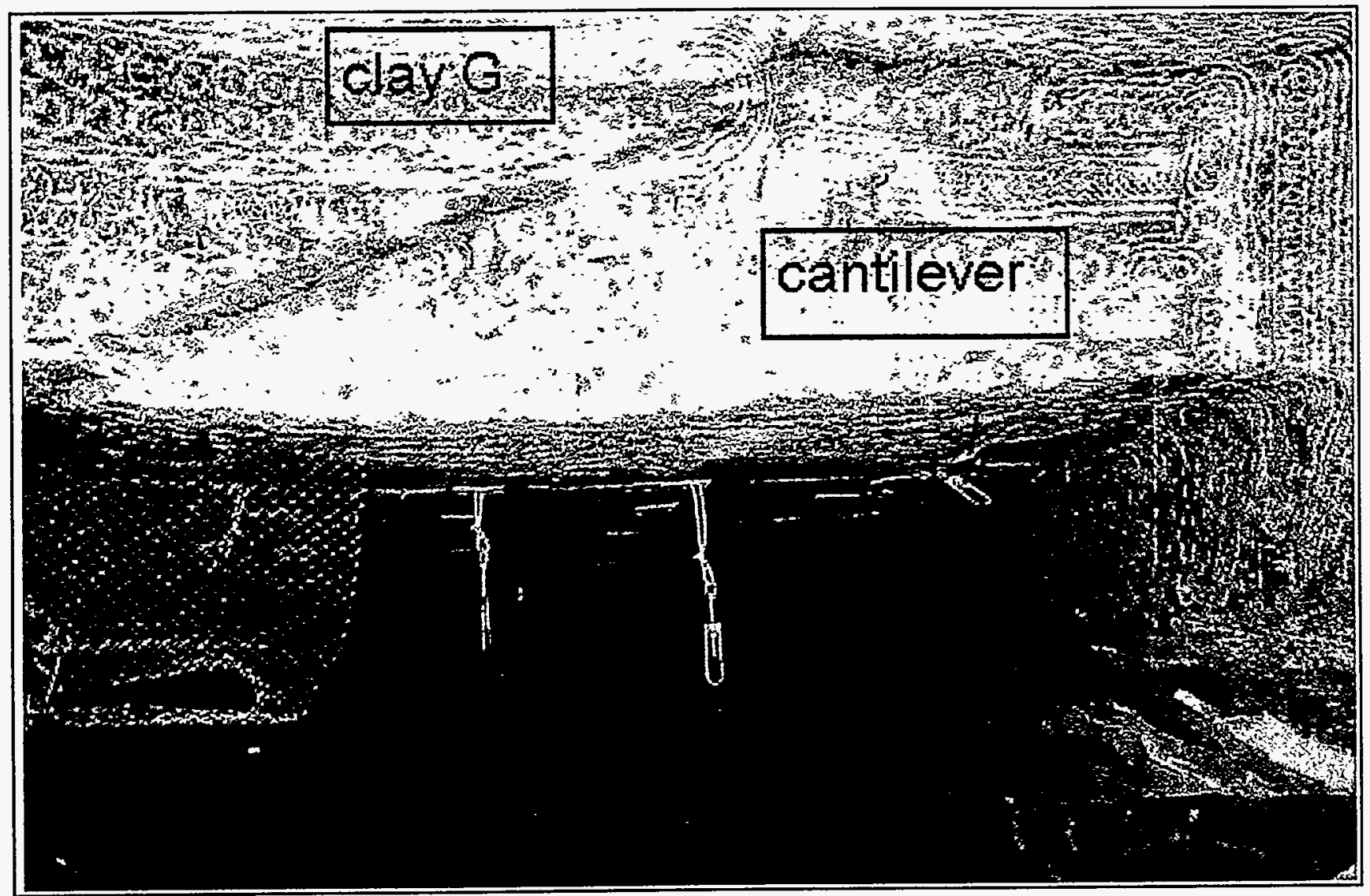

\section{MALEKI TECHNOLOGIES INC.}

SOUTH 5608 MAGNOLIA

SPOKANE, WA 99223

(509) 448-7911

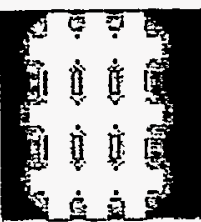




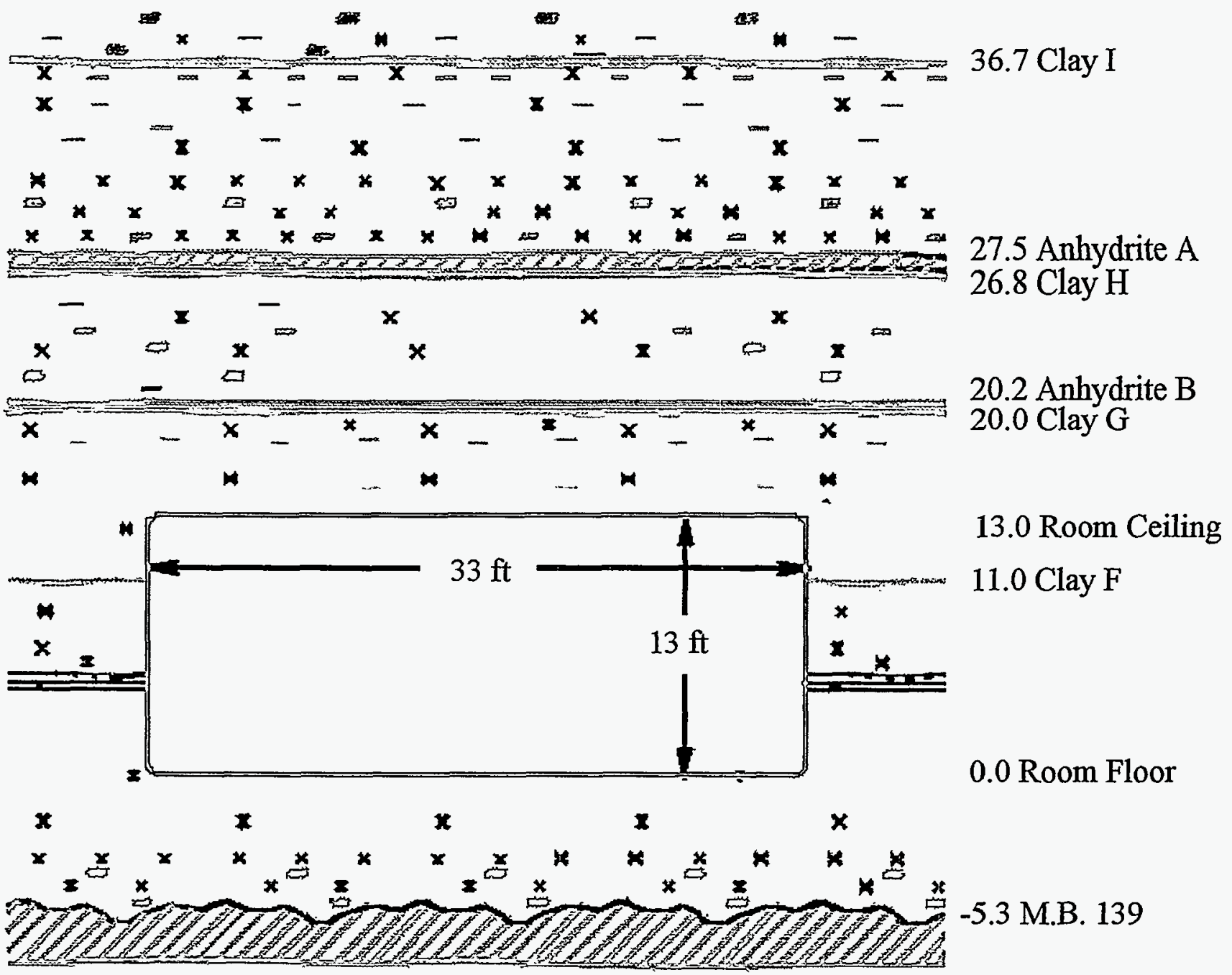

Detailed Stratigraphy at the WIPP Repository Horizon (Vertical distances are in feet from the floor of the repository) (After DOE/CAO -1996-2184, Figure 3-6) 


\title{
MINE STABILITY EVALUATION OF PANEL 1 DURING WASTE EMPLACEMENT \\ OPERATIONS AT WIPP
}

by

\author{
Hamid Maleki, Ph.D., P.E.
}

\section{INTRODUCTION}

This report and attachments were prepared as a result of contract EEG-0097 in which Maleki Technologies, Inc. (MTI), was requested to assess the stability of panel 1 at the Waste Isolation Pilot Plant (WIPP). The specific objectives of the work were defined by the Environmental Evaluation Group (EEG) as follows:

1. Assess the stability of panel 1 during the proposed operation of waste emplacement.

2. Estimate the amount of time before room closure would be expected to transfer rock loads to the waste packages.

The work consisted of (1) an analysis of geotechnical data and a review of the Department of Energy's (DOE) plans for waste emplacement in panel 1, (2) an evaluation of ground conditions based on data analysis and observations of changes in ground conditions since the first evaluation in 1993 (USBM 1993), and (3) preparation of a report and presentation of the results to EEG staff. Excluded from this study are radiological safety issues and policies. The study is based on data provided by DOE and Westinghouse Electric Corporation (operator of the site) and conversations with DOE and Westinghouse personnel. MTI cannot independently verify the accuracy of the data within the scope of this study and recommends independent evaluations of data gathering, quality assurance procedures, and structural designs. The operator has the ultimate responsibility for structural designs and has expressed a strong commitment to ensuring worker safety. 
The schedule for the receipt of the waste, including the time of the initial shipment and rate of receipt, is important for this stability evaluation. Existing modified plans (Westinghouse 1998) assume a 5.5-year time period for placing waste in panel 1 and for panel closure. Assuming a June 1998 receipt date for the first waste shipment, panel 1 is scheduled to be sealed by late 2003 . Considering the many uncertainties regarding RCRA certification and other factors and using the estimates provided by the National Transuranic Waste Management Plan, the EEG estimates 1 year for filling room 7 and 4 to 7 years for placing waste in all rooms of panel 1 (Chaturvedi 1998).

In section 2, we provide a brief historical review of the evolution of ground support systems at the WIPP site and some of the nuclear waste safety standards expected from the operator. Analyses of deformation data and bolt failure patterns are provided in section 3 to address support integrity. Expected support life after emplacement of waste is given in section 4. Summary and conclusions are included in section 5 . 


\section{REVIEW OF GROUND SUPPORT EVOLUTION AT WIPP}

WIPP is located about 30 miles east of Carlsbad, New Mexico. The site was authorized by Congress in 1979 as a research and development facility to demonstrate the safe disposal of radioactive wastes resulting from defense activities. The current mission is to receive, handle, and permanently dispose of transuranic mixed waste (both contact and remotely handled) in underground workings (panels) located 2,150 feet below the surface within a nearly 2,000-foot-thick sequence of evaporites called the Salado Formation (US DOE, 1997a).

Development of underground workings has taken place in phases. Preceding each phase, there were engineering calculations by the project architect, followed by test mining and careful geotechnical evaluations for the purpose of characterizing the site and verifying the preliminary designs. The E140 drift, one of the main arteries of the facility for air supply and access, was mined during 1983, followed by mining and design verification in the Site and Preliminary Design Validation (SPDV) area. This area has geometric and stratigraphic conditions similar to those in the waste panels; therefore, a decision was made to proceed with mining panel 1 between 1986 and 1988.

The mining schedule for panel 1 was established based on the original schedule for waste arrival and by favorable short-term monitoring results in the SPDV area. Because of delays in receiving the waste, the average life of panel 1 has been extended beyond the original functional life ( 5 years) to 17 years. This number is based on current estimates of waste arrival (June 1998). Because of timedependent fracturing of the ground, such an increase in panel life has influenced ground support decisions and necessitated improvements in monitoring systems to help assess stability.

Prior to 1986, very few areas within the facility were supported with roof bolts. Between 1986 and 1988, more than 9,000 bolts were installed in the facility, particularly in the E140 drift. By 1990, most areas in the underground facility had been systematically bolted with 6- to 10-foot-long, grade75, mechanically anchored bolts (Peterson, 1995). In 1991, a secondary support system, consisting of wire mesh, expanded metal, channel steel, and point-anchored threaded rebar, was installed in room 1, panel 1, to help extend the life of this room. Between 1992 and 1996, other secondary support systems, including mechanical bolts, resin point-anchored threaded rebar (with and without slip nuts), and cable mesh, were installed in portions of panel 1 and E140. A tertiary support system 
was designed by the operator and installed in S1950 and room 7 during 1997-1998. In addition, a laboratory investigation was initiated to test and compare the load-carrying capacity of mechanical bolts and a variety of yielding cable bolts under the influence of combined tensile and lateral offset loading conditions (Peterson 1995). No tests were conducted on the tertiary support system (No. 7 threaded rebar) installed in room 7. More recently, environmental factors contributing to premature failure of bolts have been studied (Terrill and others 1995).

To monitor ground conditions and evaluate support performance, an intensive geotechnical monitoring program was implemented. This program consisted of monitoring strata deformation (figure 1), bolt loads, locations where bolts failed, strata fracturing, and lateral offsets at clay $\mathrm{G}$ (see photo on report cover) and other horizons. These measurements have been very helpful in improving understanding of strata behavior and in increasing the operator's ability to assess ground conditions.

The author has had a unique opportunity to observe changes in ground conditions at the WIPP site and perform independent stability evaluations since 1993. Between 1993 and 1995, as chairman of the U. S. Bureau of Mines (USBM) Stability Evaluation Committee, the author observed, mapped, and evaluated ground conditions throughout the underground workings and prepared annual reports (USBM 1993, 1994, 1995) as required by the Land Withdrawal Act, Public Law 102-579. During 1996, at the request of EEG for an independent evaluation, MTI completed a more comprehensive review and developed a preliminary mathematical model for predicting room closure and stability using the data obtained by the Westinghouse geotechnical group at 119 instrumented clusters. The result of this work was peer reviewed and presented at the 36th U.S. Symposium on Rock Mechanics (Maleki and Chaturvedi 1997).

MTI's 1996 evaluation and subsequent publications addressed difficulties with "assuring stability" in an underground repository and suggested that it was more reasonable to expect stability "with a high degree of confidence." The study concluded that portions of panel 1 may be used for waste emplacement with a reasonable degree of confidence and recommended improvements in monitoring and supplementary ground support systems that could increase confidence in the designs.

The stability of the roof during waste emplacement operations has been a concern because during this period, access will be limited and supplementary support cannot be installed. To overcome this 
difficulty, the operator has designed a tertiary support system that consists of threaded rebar in 3-in holes (to allow for lateral offset), mechanical bolts, wire mesh, wire rope, cable lacing, and crushable plate pads (Terrill and others 1995). The operator is considering other options also, including mining the immediate roof beam (to clay $\mathrm{G}$ ) and/or abandoning portions of panel 1 (Westinghouse 1998). Current plans consider installing this pattern support just shortly before waste emplacement operations in each room to minimize the potential for roof falls during the waste emplacement period (for example, 1 year, assuming no significant delays). 


\section{ANALYSIS OF ROOF STABILITY AND SUPPORT INTEGRITY}

This evaluation does not indicate any significant change in the overall convergence rate and apparent stability of panel 1 since 1996, except that (1) fractures in the roof are propagating to the eastern portion of the S1950 drift and (2) the extent of fracturing has increased along most rooms in panel 1 and the S1600 drift with time. Appendix A presents photographs of the roof and rib conditions, which are useful for comparing fracturing at selected locations in panel 1 . The photographs also show the supplementary support systems installed to control ground movements.

This evaluation is based on a review of deformation data for panel 1 during a period prior to March 1998 and comparisons with similar data analyzed in 1996 (MTI 1996), underground observations of roof conditions, a review of borehole measurements and lateral offsets at clay seams (US DOE 1997b), bolt failure data, and lateral pillar deformation data. Deformation data included in this analysis were extracted from plots and are summarized in figures 2 through 5 . The analysis consists of relative roof deformation (figure 2), roof deformation rate in inches per year (figure 3), total rooffloor convergence (figure 4), and roof-floor convergence rate in inches per year (figure 5).

To assess roof stability, three criteria were established in our 1996 study. These criteria focused on changes in both vertical and horizontal deformation rates in the mine roof. Vertical deformation was quantified using both measured roof deformation rate and roof-floor convergence rate. Horizontal deformation rates were obtained through borehole observations at clay $\mathrm{G}$ and other horizons. In addition, observations of the extent and location of both shear and tensile fractures in the roof were used as an indicator of severity of damage (Maleki and Chaturvedi 1997). The first two criteria are routinely used in mining to assess roof stability (Maleki 1988; Maleki and others 1993; Serbousek and Maleki 1988). Both laboratory (Peterson 1995) and field investigations (Maleki and others 1985, 1986a) show that excessive asymmetrical horizontal movements are detrimental to support integrity. These asymmetrical horizontal movements are intensified where cantilevers form in the mine roof. (The photo on the report cover, which was taken in the E140 drift during removal of the roof beam, shows a cantilever.) The 1996 study concluded that the immediate roof is fracturing along portions of panel 1 and cantilevers are forming in portions of all rooms, except possibly in room 2 and the $\mathrm{S} 1950$ drift. 
Figure 6 presents a comparison of roof-floor convergence rates for 50 locations in panel 1 and the access drifts and indicates that the average convergence rate has not changed significantly for the entire panel since 1996. This conclusion is based on statistical tests of significance for paired samples (measurements of convergence rates at the same locations in 1996 and 1998). Figure 6 also compares convergence rates for 1996 and 1998 evaluations and shows that the rate is unchanged in a number of locations (points near 1:1 line), reduced at others, and increased at still others. The convergence rates are increasing in the S1950 drift, a measurement that is in agreement with observations of fracturing in this drift. Note that lateral roof movement influences convergence rates, particularly where these lateral movements are large.

Roof deformation rates (figure 3) are generally lower than those reported in 1996. This reduction is influenced by two factors: replacement of extensometers in newly drilled boreholes and installation of supplementary support. Measured roof deformation is reduced when extensometers are reinstalled in new boreholes because extensometer wires are not stretched horizontally (at least temporarily) by lateral offset. These effects can be visualized by comparing the measurements for two neighboring extensometers located toward the northern portion of room 1 (figure 3).

There is considerable variation in the rate of lateral deformation (offset) at clay $G$ (figure 7), ranging from 0 to approximately 1 inch per year. These measurements are extracted from the most recent (1995-1996) geotechnical analysis available and thus do not reflect present conditions (localized larger deformation rates are possible for 1997-1998). They are, however, in good agreement with our observations in 1996, confirming that the least amount of lateral offset is in room 2 and the maximum offset is in rooms 1 and 4 through 7. Total measured lateral offset in panel 1 varies from 3 to 4 inches.

Although maximum lateral offset occurs at clay $\mathrm{G}$, there is movement at clay $\mathrm{H}$ and in higher horizons into the roof (Stormont 1990). The measured lateral offset rate varies from 0 to 0.4 inches/year in panel 1 based on the most recent geotechnical analysis report. Structural integrity of the beam between clays $\mathrm{G}$ and $\mathrm{H}$ is important to the stability of the immediate roof because this zone is the anchorage horizon for most roof bolts. 
The location of rock bolt failures and patterns are influenced by vertical and lateral loads, bolt grade, installation practice (Maleki and others 1985), environmental factors (MTI 1996; Westinghouse 1998), rate of ground movement, and fatigue (MTI 1996; Westinghouse 1998). As expected (MTI 1996), there has been a significant increase in the number of bolt failures in panel 1 since 1996 (figure 8). Since a great majority of the failed bolts are of the mechanical anchor type, this increase in the rate of overall bolt failure is indicative of the loss of effectiveness of mechanical bolts. This is not necessarily a safety concern because (1) wire mesh is being installed over the mechanical bolts in panel 1 to prevent free fall of bolt hardware and (2) there is a secondary bolting pattern in which 12- to 13-foot-long threaded rebar was installed in most rooms between 1991 and 1996.

The integrity of this secondary pattern bolting is important because it determines whether there is a need for a systematic tertiary support system. Figure 9 shows the approximate location of threaded rebar failure and the type of failure in each calender year since 1995. Note that the majority of the failures occurred in rooms 1 and 7 . The operator has installed a tertiary support system in room 7 and is replacing failed bolts in other rooms, among other measures.

The time lag between installation of nonyielding secondary threaded rebar and rebar failure in room 7 is approximately 2 years. This time-to-failure is consistent with the measurements of lateral offset rates and the capability of threaded rebar to handle both axial and lateral deformation (figure 7). Assuming a lateral offset rate of 1 inch per year, the bolts will be in contact with the wall of the borehole within approximately 1 year, yield under the combined influence of axial and vertical loading soon after, and possibly fail at ultimate strain (Holmberg 1991) during the second or third year. Variations from this pattern can occur, depending on installation practice, spatial variation in lateral offset rates, and variations in bolt material properties, among other factors (considering lower lateral and vertical deformation rates in room 2 and improved flexibility of the tertiary support system, the time-to-failure can be twice as long at some locations). Since it will not be possible to replace failed bolts during and after waste emplacement operations and considering the fractured nature of the roof beam, failure of some bolts can increase the failure rate in other bolts and lead to roof collapse.

Roof stability is influenced by pillar behavior (Maleki and Hollberg 1995; US DOE 1991). Most rib extensometers installed in panel 1 (except in room 2) are showing slight increases in the rate of 
lateral movement instead of the normally expected decrease. Considering rib movement patterns, horizontal offset at clay $\mathrm{G}$, and rates of roof and floor deformation, room 2 is currently the most stable when compared to the other rooms. 


\section{ANTICIPATED TIME FOR TRANSFERRING ROOF LOADS TO THE WASTE}

Present plans for emplacement of transuranic waste consist of installing three stacks of seven-packs or standard waste boxes and covering with a layer of backfill (supersack) in rooms 13 feet high (US DOE 1995). Backfill sacks (supersacks and minisacks) contain magnesium oxide to provide chemical control over the solubility of radionuclides. Considering the height of the waste drums, slipsheets , supersacks, and the protruded length of the roof support assembly (4 inches, assuming bolt tails to be cut), there will be approximately 18 inches of clearance between the roof support and the backfill or 42 inches between the roof support and the waste drums. The distance between the roof support assembly and the waste drum is the controlling factor because the supersacks may be penetrated by the roof support first, resulting in the flow of magnesium oxide grains to the spaces between the waste drums, before any significant load is transferred to the waste box. The time between emplacement of waste and load transfer to the waste box is referred to here as "time lag".

The time lag is influenced by roof and pillar behavior and supplementary support effectiveness. Assuming an effective supplementary support system (no roof falls) and linear pillar behavior (no abnormal change in pillar dilation rate), the time lag can be estimated using the rate of convergence. The rate of convergence is estimated using both the statistical model developed for the site (Maleki and Chaturvedi 1997) and a linear extrapolation of existing measurements.

Figure 10 provides a comparison of predicted (MTI 1996) roof-floor convergence and measured range of convergence in panel 1 in 1998. Since there is good agreement between calculated average convergence and actual measurements, the model can be reasonably used to predict future deformation. Using a waste emplacement period of 5 years, there will be approximately 14 inches of additional convergence, which is insufficient time for bolts to transfer load to the drums.

Table 1 shows the minimum and maximum expected change in convergence for two locations in rooms 1 and 2 using a 4- to 7-year waste emplacement schedule and a linear extrapolation of present convergence rates. Again, load transfer to the waste drums is not expected during the waste emplacement period. 
Table 1.-Expected maximum and minimum change in convergence for a 4-to 7-year waste emplacement schedule, inches.

\begin{tabular}{ccc}
\hline Location & Four-year schedule & Seven- year schedule \\
\hline Room 1 & 14.8 & 25.9 \\
Room 2 & 8.8 & 15.4 \\
\hline
\end{tabular}

The time lag can be significantly shorter, depending on the choice of supplementary support systems. If external support systems (such as cribs) are used in conjunction with tertiary pattern bolting, there will be very little likelihood of roof falls during the waste emplacement operations within panel 1 . This is because the effectiveness of the threaded rebar depends on the amount of lateral offset and a stable anchorage horizon, while the external support systems (1) are less sensitive to lateral offset loads than threaded rebar and (2) they transfer roof load directly to the floor (Maleki and others 1986b). Note that measurements of offset at clays $\mathrm{G}$ and $\mathrm{H}$ indicate that the beam outlined by clays $\mathrm{G}$ and $\mathrm{H}$ (anchorage horizon) will continue to move in horizontally.

On the basis of the available data, it is difficult to estimate the time to roof collapse with a high degree of confidence if internal tertiary support systems will be used without external support systems. Assuming no significant changes in either lateral or vertical loading rates and using the timing of threaded rebar failures in room 7 , the potential for roof falls significantly increases in some rooms beyond approximately 2 years after installation of a tertiary support system. If waste is emplaced during this period, there will be no opportunity to replace failing bolts, which may accelerate bolt failures in a domino fashion and increase the potential for the collapse of broken immediate roof. Using current estimates of waste inflow, the operator plans to complete waste emplacement within a year. The operator is also considering abandonment of a portion of a room (in less than a year) if signs of instability are detected by both existing and improved monitoring systems. Ideally, roof stability should be monitored with several redundant instruments to ensure that loss of one instrument will not adversely influence stability assessment and the decision-making process. 
Factors that could shorten this time-to-collapse ${ }^{1}$ are (1) significant changes in pillar dilation rates as excavations age or panel life is extended to accommodate delays in receiving waste, (2) mining in panel 2, which could transfer load toward panel 1, depending on panel 2 designs, and (3) failure of the bolt anchorage horizon.

To increase confidence in estimates of time-to-collapse, it is useful to consider (1) measuring load deformation properties for threaded rebar under combined axial and lateral loading conditions and (2) evaluating pillar stability through analyses of stress (Maleki and Hollberg 1995), strain, or possibly wave propagation characteristics (Jung 1991; Maleki and Hollberg 1995).

Alternately, the time-to-collapse can be increased with a high degree of confidence by considering the following suggestions. (1) Use only the most stable portions of panel 1 (such as room 2) for waste emplacement, (2) install external support systems in conjunction with internal support systems, (3) plan mining activities in panel 2 to minimize significant load transfer toward panel 1 , and (4) avoid extending panel life.

The operator is also considering mining the immediate roof rather than installing tertiary support. This option should be analyzed further to determine whether or not such a change in the volumetric extraction ratio will influence stability in other rooms in time and/or influence load transfer to panel 2. Mining layouts and functions are more different in panel 1 than at other locations where the highly fractured roof beam has been removed (US DOE 1994).

${ }^{1}$ Excluding dynamic events (such as earthquakes), which we were not directed to study. 


\section{SUMMARY AND CONCLUSIONS}

This report provides an (1) analysis of roof stability in panel 1 during the proposed waste emplacement and (2) an estimate of the amount of time before room closure would be expected to transfer roof loads to the waste drums.

The following conclusions have been derived on the basis of observations of ground behavior since 1993, analysis of deformation data provided by DOE, and professional judgment.

- Overall rates of convergence and apparent stability of panel 1 have not changed significantly since our 1996 evaluation. The extent of fracturing is related to the amount of deformation and both will increase over time. In response to these changes, the operator has increased the amount of supplementary support efforts in panel 1 , among other measures.

- The time lag for roof loads to transfer to waste drums depends on the choice of tertiary support systems. If both internal and external support systems are installed and ground behavior is linear (nonaccelerating), there will be little likelihood that roof loads will be transferred to the waste during the estimated 4- to 7-year waste emplacement schedule for panel 1.

- Time to roof collapse can not be estimated with a high degree of confidence on the basis of available data if internal tertiary support systems are used without external support systems, such as cribs. The potential for roof falls is expected to be low within the first year and increase significantly in some locations approximately 2 years after installation of tertiary support. Using current estimates of waste inflow, the operator plans to complete waste emplacement in each room within a year and has provisions to abandon a portion of a room if signs of instability are detected in less than a year.

- Stability and longevity can be improved by considering the following.

(1) Use of the most stable rooms in panel 1 (such as room 2).

(2) Installation of external support systems in conjunction with the use of tertiary internal support. 
(3) Design of mining layouts and activities in panel 2 to reduce load transfer toward panel 1.

(4) Avoidance of any significant delay.

(5) Improvements in the existing monitoring system. 


\section{REFERENCES}

Chaturvedi, L., 1998. Letter to Hamid Maleki dated April 21, 1998, regarding waste emplacement schedule. Environmental Evaluation Group.

Holmberg, M.. 1991. The Mechanical Behavior of Untensioned Grouted Rock Bolts. Department of Soil and Rock Mechanics, Stockholm.

Jung. 1991. Mapping Fracture Zones in Salt Using High-Resolution Seismic Tomography. Ph.D. Thesis, Colorado School of Mines, Golden, CO.

Maleki, H. 1985. "Evaluation of Rock Bolt Tension Measuring Techniques." Proc. 26th U.S. Symp. on Rock Mechanics, June 1985.

Maleki, H. 1988. "Detection of Stability Problems by Monitoring the Rate of Movement." Coal Age: Dec. 1988.

Maleki, H.. 1992. "Significance of Bolt Tension in Ground Control." Proc. Int. Symp. on Rock Support, Sudbury, ON, Canada. A.A. Balkema, pp 439-449.

Maleki H., and L. Chaturvedi. 1997. "Prediction of Room Closure and Stability of Panel 1 in the Waste Isolation Pilot Plant.” Int. Jour. Rock Mech. \& Min. Sci. 34:3-4, paper \#186.

Maleki, H., M. Hardy, and H. Brest Van Kampen. 1985. "Evaluation of Rock Bolt Tension Measuring Techniques." Proc. 26th U.S. Symp. on Rock Mechanics, Research and Engineering Applications in Rock Masses, A.A. Balkema, pp 425-437.

Maleki, H., and Hollberg. 1995. "Structural Stability Assessment Through Measurements." Proc. Int. Soc. of Rock Mech. Workshop on Rock Foundations, A.A. Balkema, pp 449-454, Tokyo, Japan. 
Maleki, H., and others. 1986a. "Impact of Mechanical Bolt Installation Parameters on Roof Stability." Proc. 27th U.S. Symp. on Rock Mechanics. University of Alabama, pp 526-536.

Maleki, H., and others. 1986b. "Tailgate Support Evaluation at Plateau Mining Company." Proc. 5th Conf. on Ground Control in Mining. West Virginia University, Morgantown, WV

Maleki, H., and others. 1993. "A Case Study of Monitoring Changes in Roof Stability." Int. Jour. of Rock Mech. \& Mining Science. vol. 30, no. 7.

MTI, 1996. Stability Evaluation of Panel 1 Rooms and the E140 Drift at WIPP. Report to Environmental Evaluation Group. Publ. in EEG-63.

Peterson, G. 1995. Final Report on Rockbolt Testing for WIPP. Internal report prepared by Rock Mechanics Assist for Westinghouse Engineering, pp. 11.

Serbousek, M. and H. Maleki. 1988. "Use of Ground Movements for Detection of Roof Stability Problems." Proc. 8th Int. Data Control Conf., West Germany. May 1988.

Stormont, J.C. 1990. Discontinuous Behavior Near Excavations in a Bedded Salt Formation. Sandia National Laboratories, SAND89-2403.

Terrill, L., and others. 1995. "Analysis of Rock Bolt Performance at the Waste Isolation Pilot Plant." Proc. 14th Conf. On Ground Control in Mining. West Virginia University, Morgantown, WV.

U. S. Bureau of Mines. 1993. Annual Stability Evaluation of WIPP.

U. S. Bureau of Mines. 1994. Annual Stability Evaluation of WIPP.

U. S. Bureau of Mines. 1995. Annual Stability Evaluation of WIPP.

U.S. Department of Energy. 1991. Report of the Geotechnical Panel on the Effective Life of Rooms in Panel 1. DOE/WIPP 91-023. 
U.S. Department of Energy. 1994. Investigation of the Advantages of Removing Highly Fractured Roof Beams. DOE/WIPP 94-025.

U.S. Department of Energy. 1997a. Waste Isolation Pilot Plant Safety Analysis Report. DOE/WIPP95-2065, Rev 2.

U.S. Department of Energy. 1997b. Geotechnical Analysis Report for July 1995-June 1996, DOE/WIPP-97-2261 .

Westinghouse Electric Corporation. 1998. Annual Ground Control Operating Plan for the Waste Isolation Pilot Plan. Westinghouse Geotechnical Engineering, Feb. 1998. 
FIGURES 


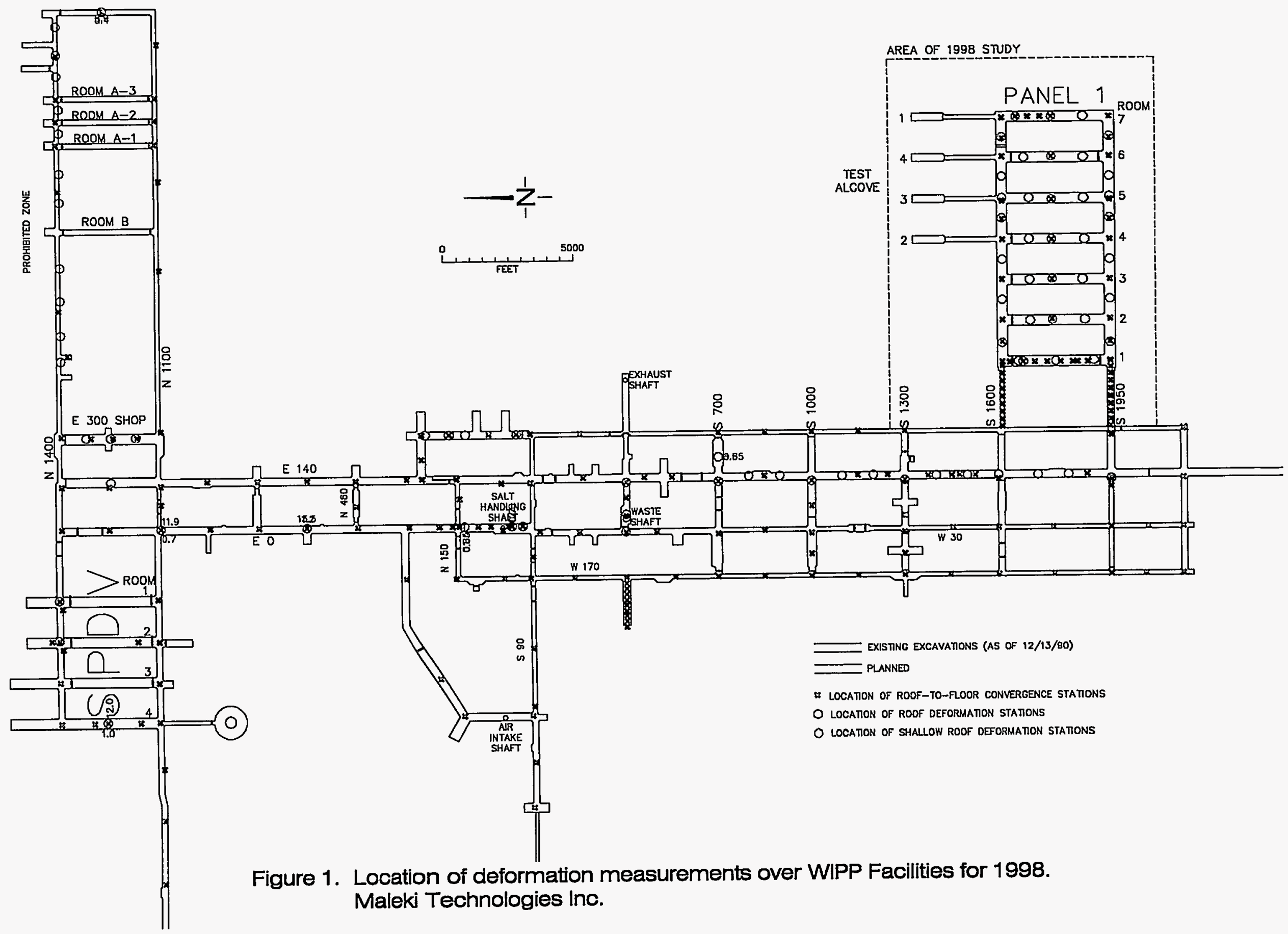



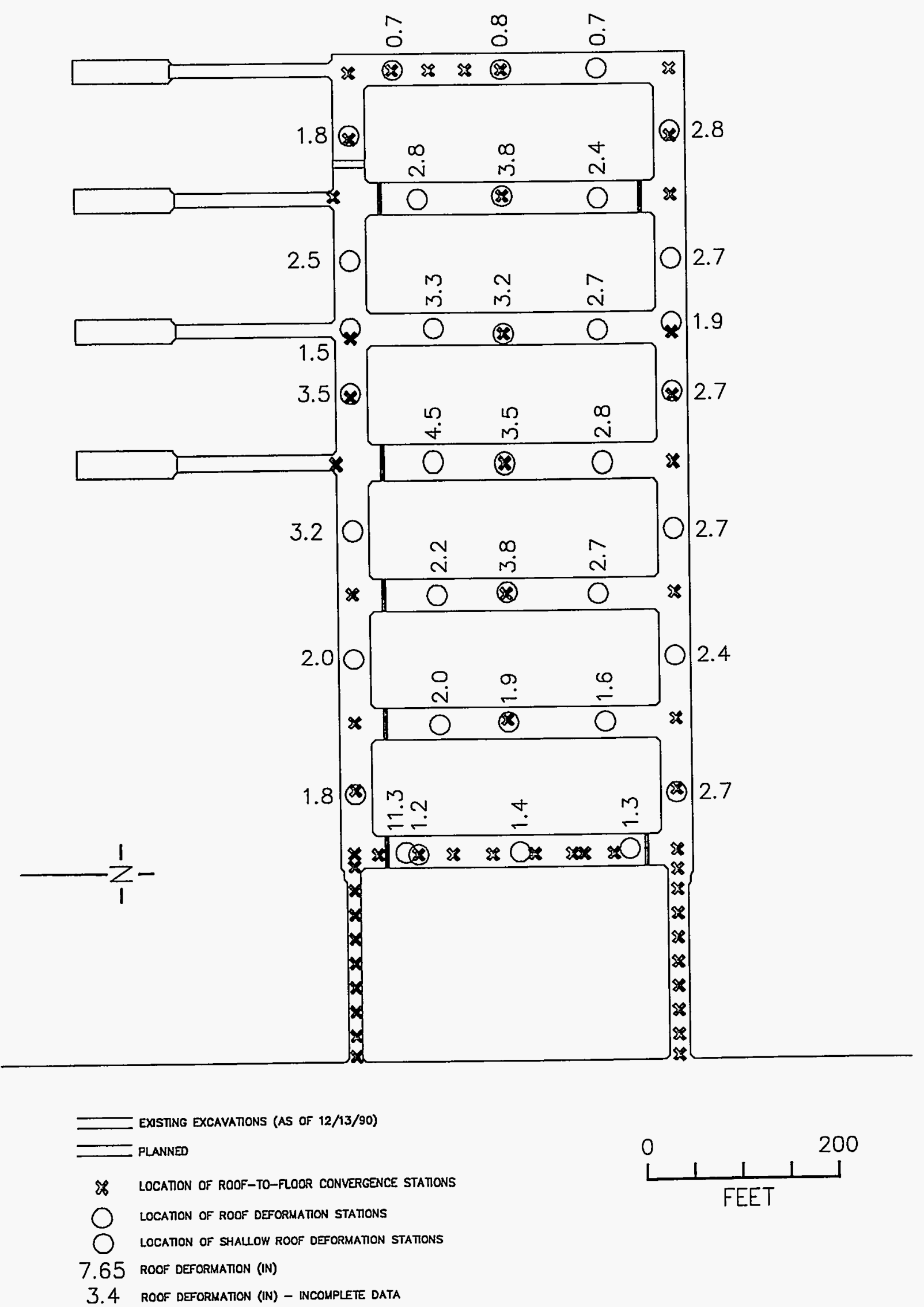

Figure 2. Vertical roof deformation (in) in panel 1 for 1998 review. Malekl Technologies Inc. 


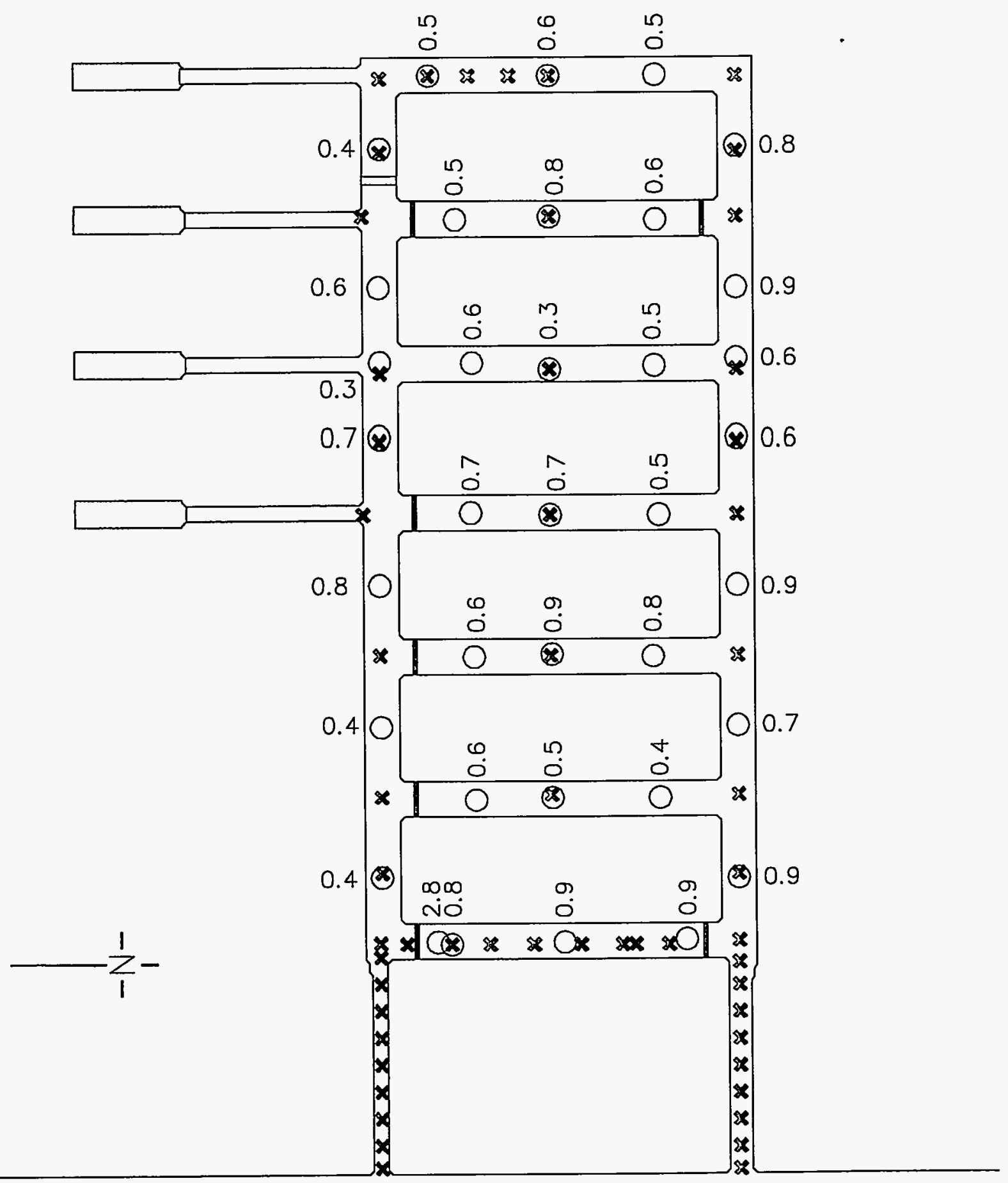

EXSTING EXCAVATIONS (AS OF $12 / 13 / 90$ )

PLANNED

2 LOCATION OF ROOF-TO-FLOOR CONVERGENCE STATONS

LOCATION OF RODF DEFORMATION STATIONS

LOCATION OF SHALLOW ROOF DEFORMATION STATIONS

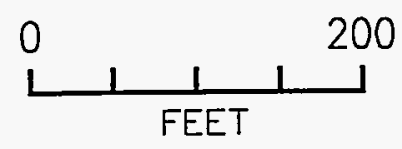

7.65 DEFORMATION RATE (IN/MR)

3.4 DEFORMATION RATE (IN/MR) - INCOMPLETE DATA

Figure 3. Vertical roof deformation rate (in/yr) in panel 1 for 1998 review. Maleki Technologies Inc. 


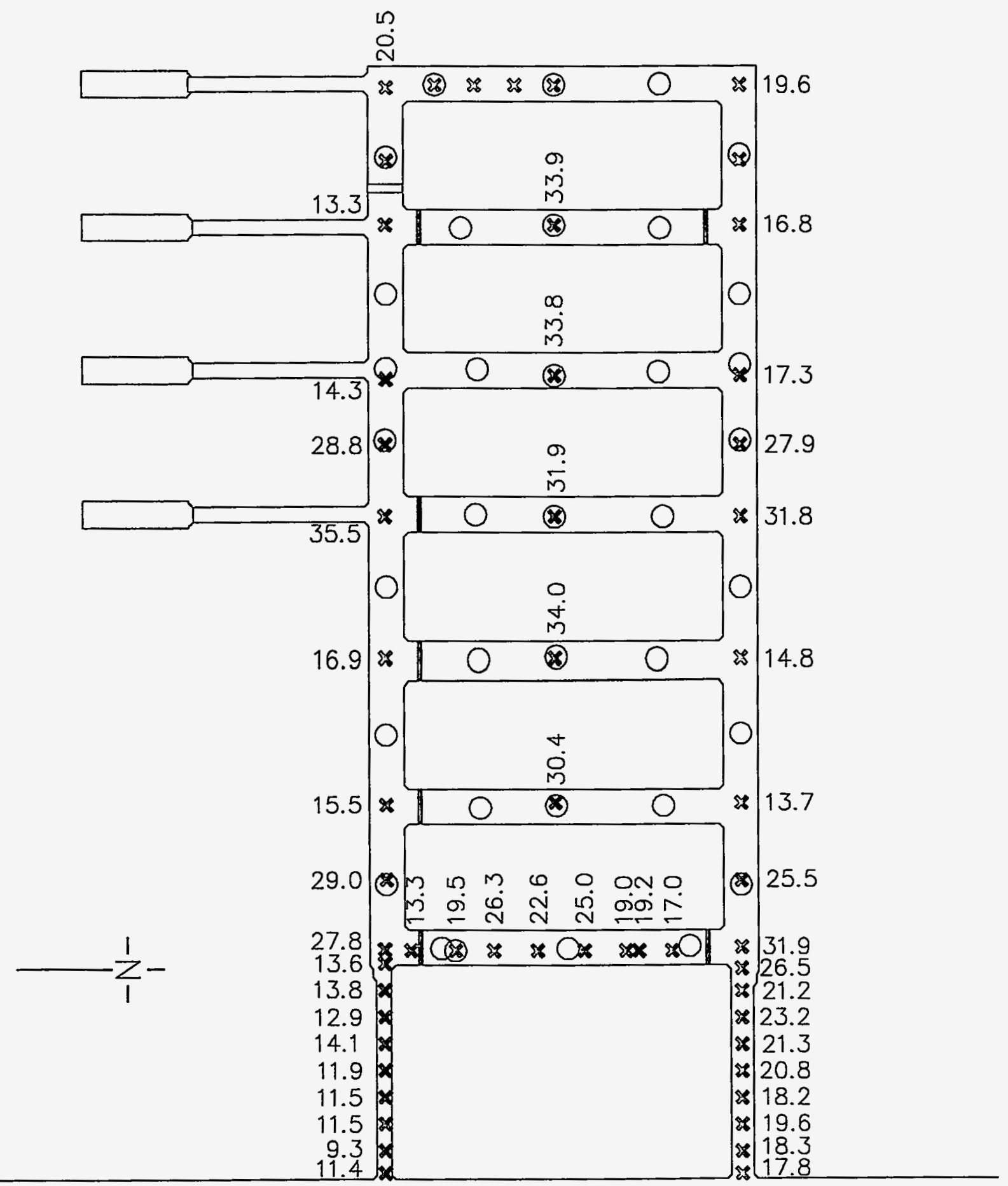

ב EXSTING EXCAVATIONS (AS OF 12/13/90)

= PLANNED

LOCATION OF ROOF-TO-FLOOR CONVERGENCE STATIONS

L LOCATION OF ROOF DEFORMATION STATIONS

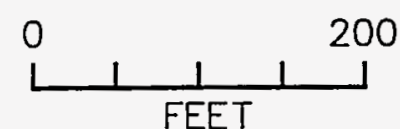

LOCATION OF SHALLOW ROOF DEFORMATION STATIONS

7.65 ROOF-TO-FLOOR CONVERGENCE (IN)

3.4 ROOF-TO-FLOOR CONVERGENCE (IN) - INCOMPLETE

Figure 4. Roof-to-floor convergence (in) in panel 1 for 1998 review. Maleki Technologies Inc. 


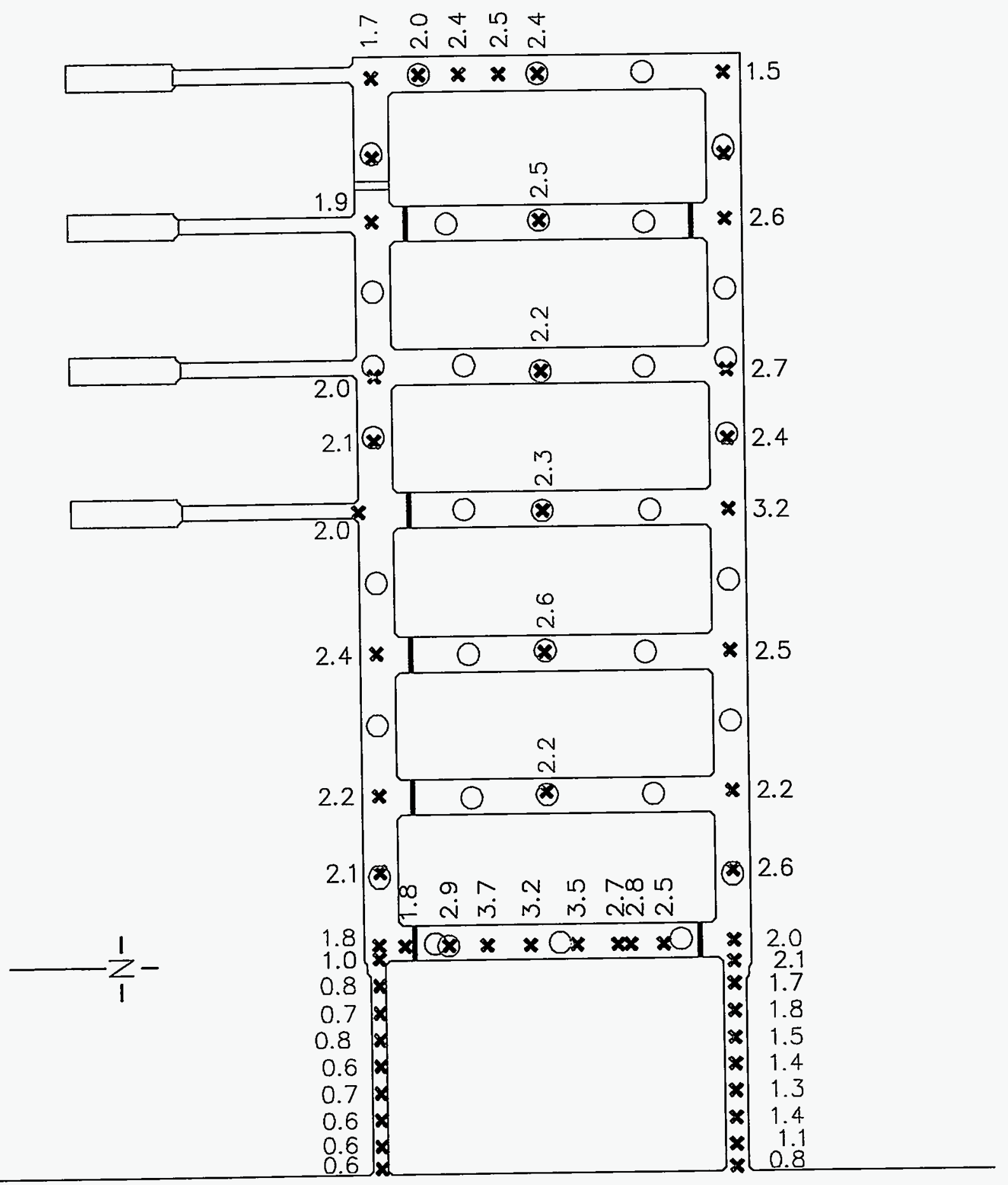

EXISTING EXCAVATIONS (AS OF $12 / 13 / 90$ )

\begin{tabular}{l} 
ב EXISTING EXCAVATIONS (AS OF $12 / 13 / 90$ ) \\
\hline FLANNED \\
L LOCATION OF ROOF-TO-FLOOR CONVERGENCE STATONS \\
LOCATION OF ROOF DEFORMATION STATIONS \\
7.65 LOCATION OF SHALLOW ROOF DEFORMATION STATIONS \\
3.4 CONVERGENGE RATE (IN/MR) - INCOMPLETE DATA
\end{tabular}

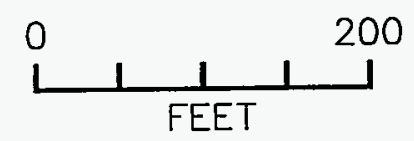

Figure 5. Roof-to-floor convergence rate (in/yr) in panel 1 for 1998 review. Maleki Technologies Inc. 


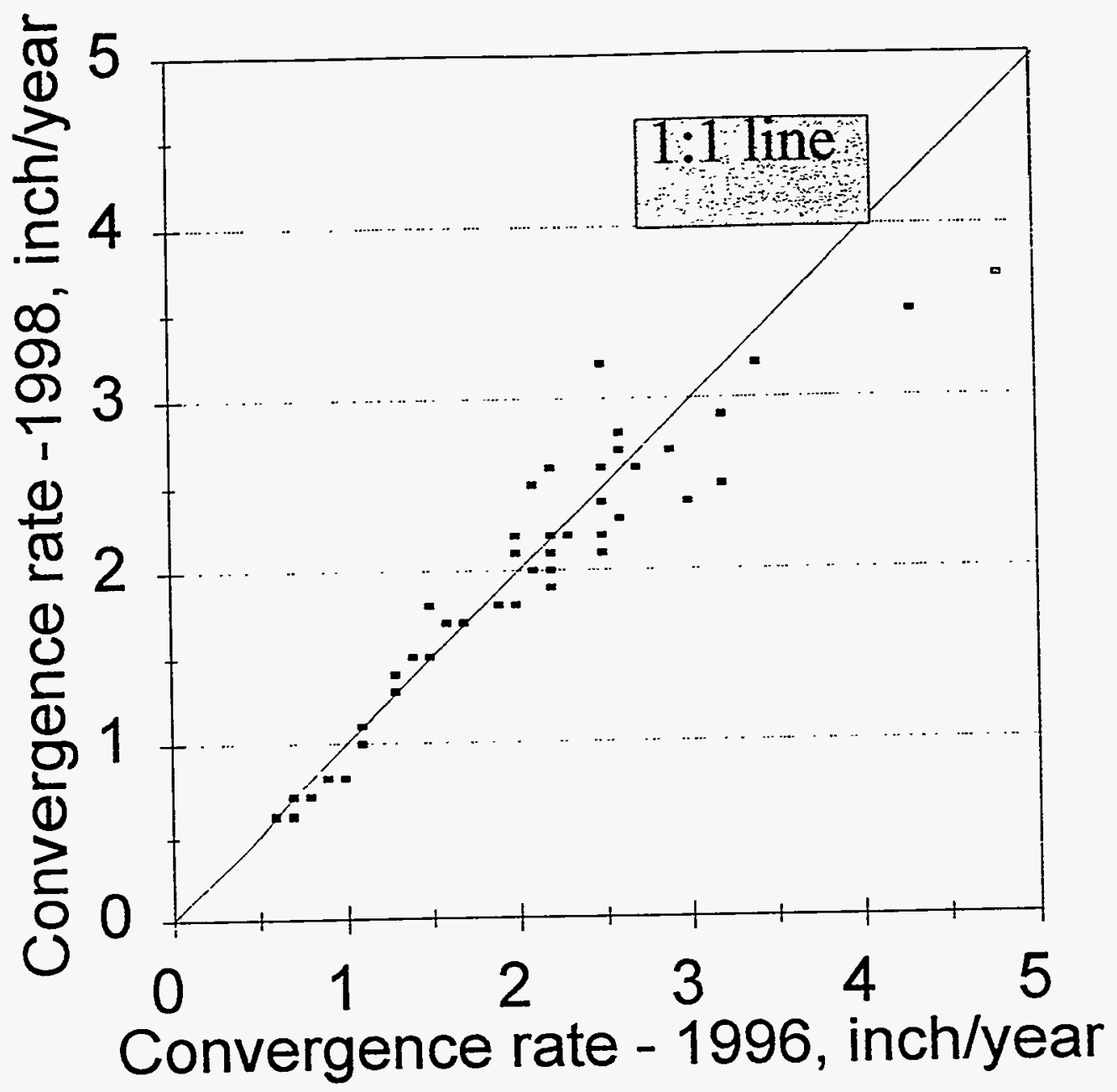

Figure 6 - Compared convergence rates for 1996 and 1998 evaluations. 


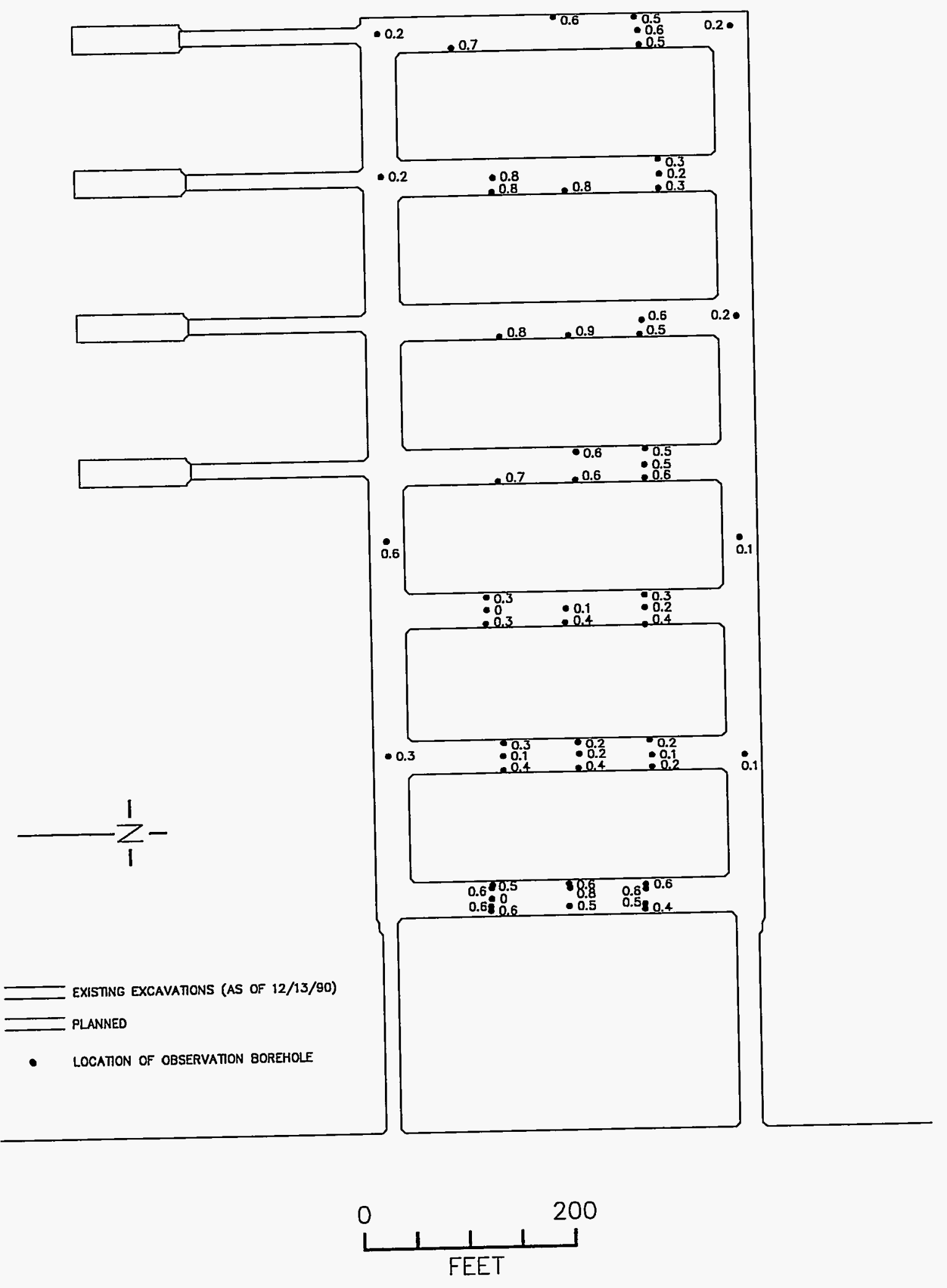

Figure 7. Horizontal deformation rate, (in) at clay G during 1995 - 1996 period. Maleki Technologies Inc. 


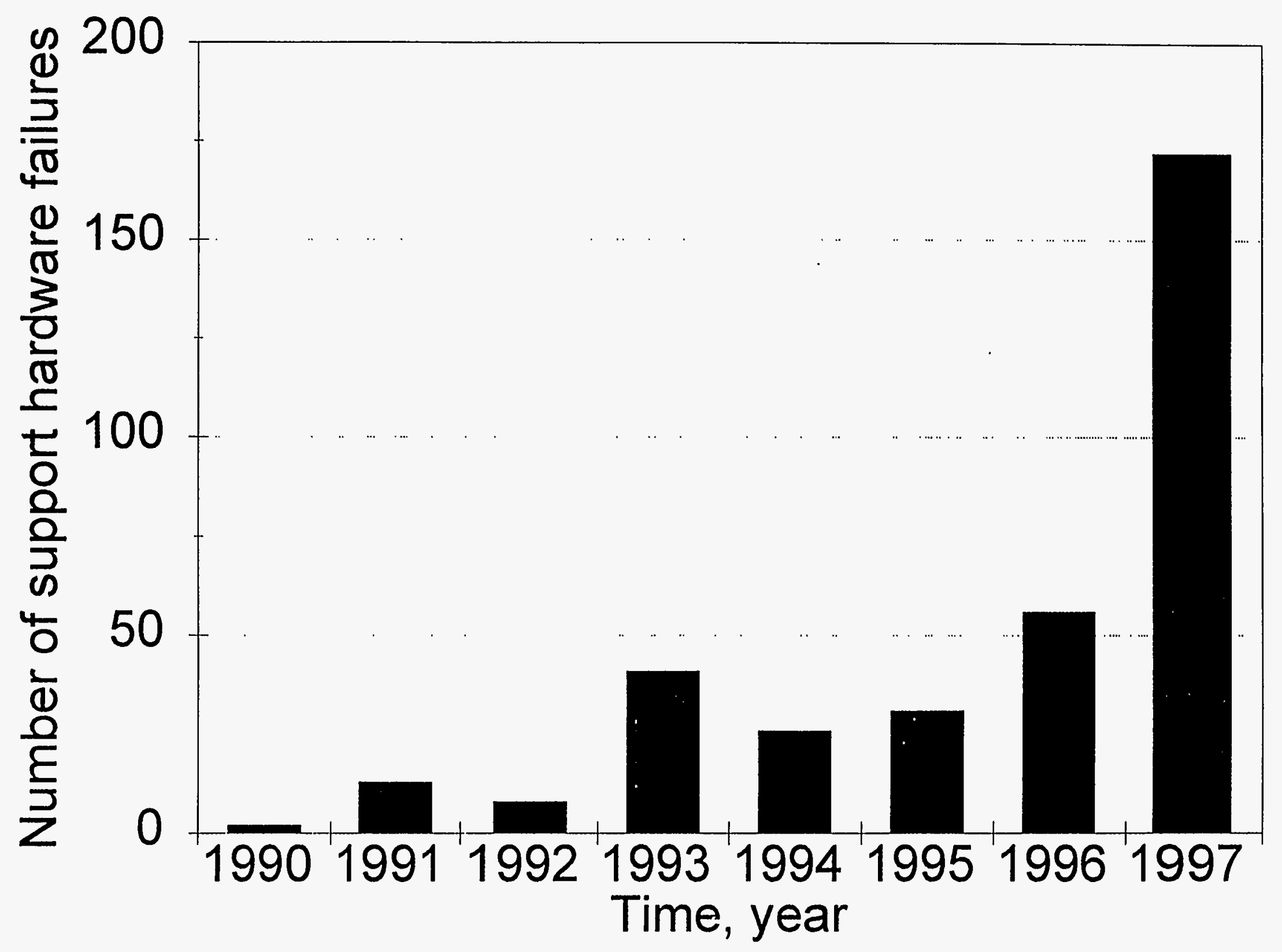

Figure 8 - Total number of roof bolt assembly failures in Panel 1. 


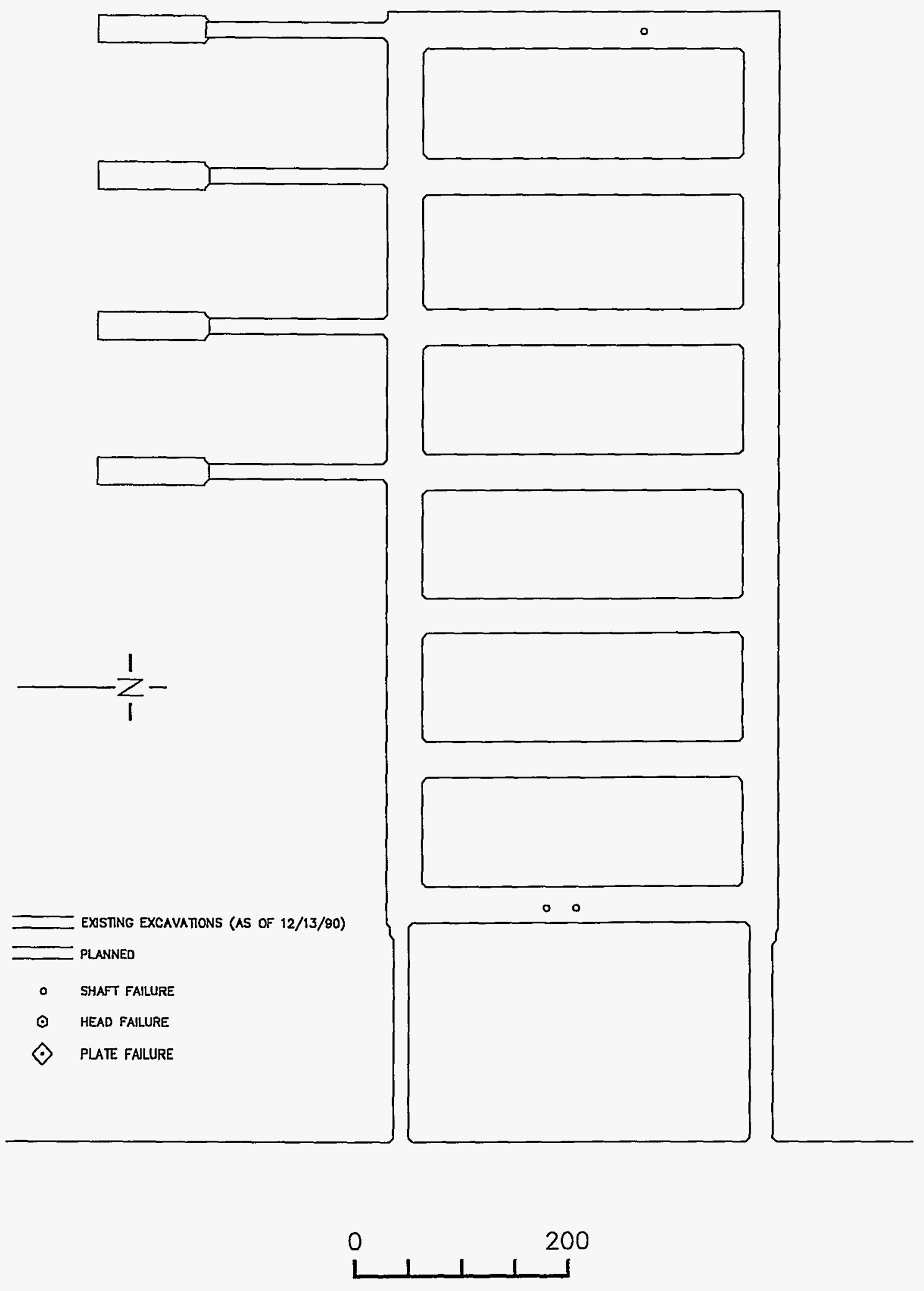

Figure 9a. Approximate location of threaded rebar failure in panel 1 for 1995. Maleki Technologies Inc. 


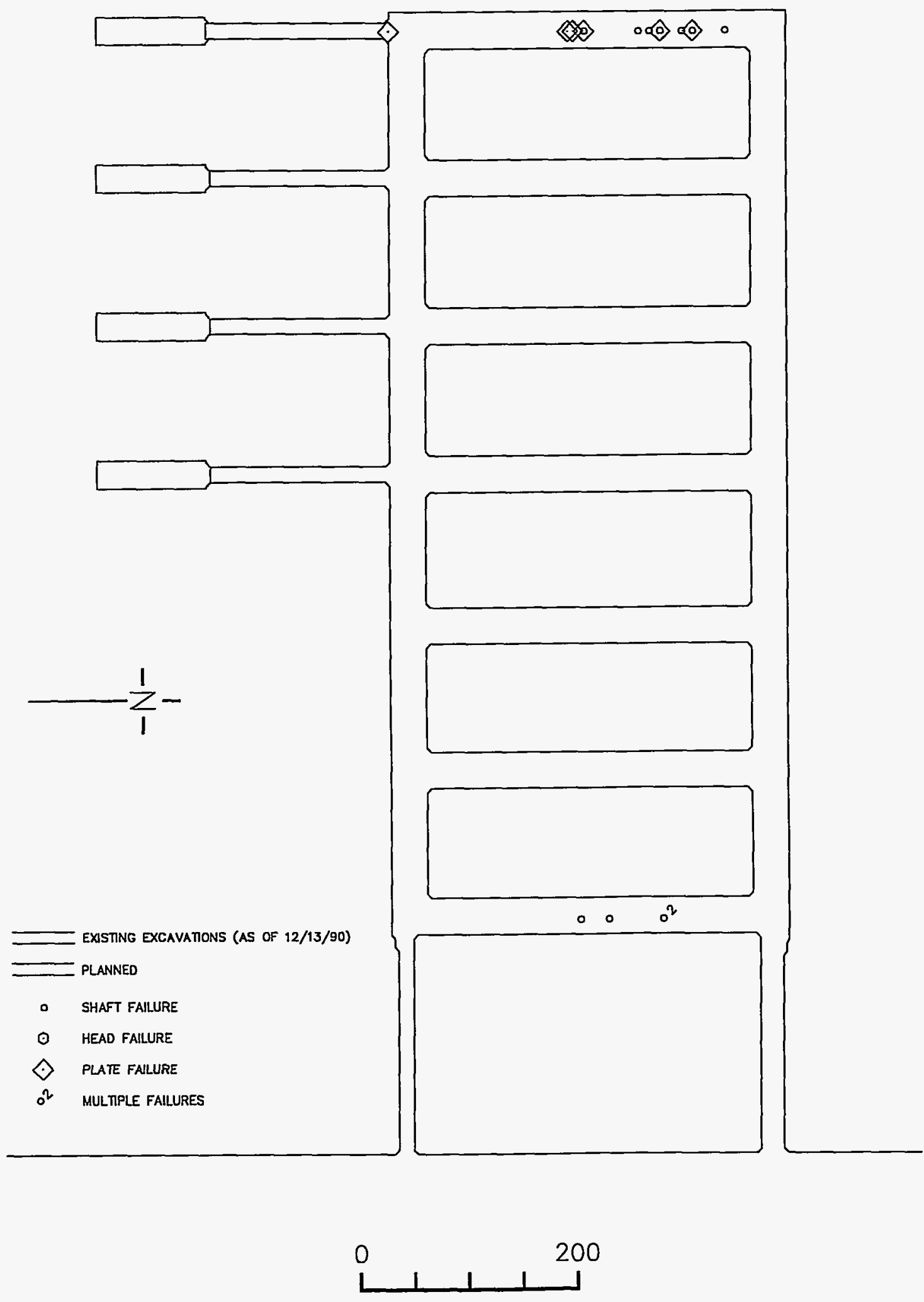

Figure 9b. Approximate location of threaded rebar failure in panel 1 for 1996. Maleki Technologies Inc. 


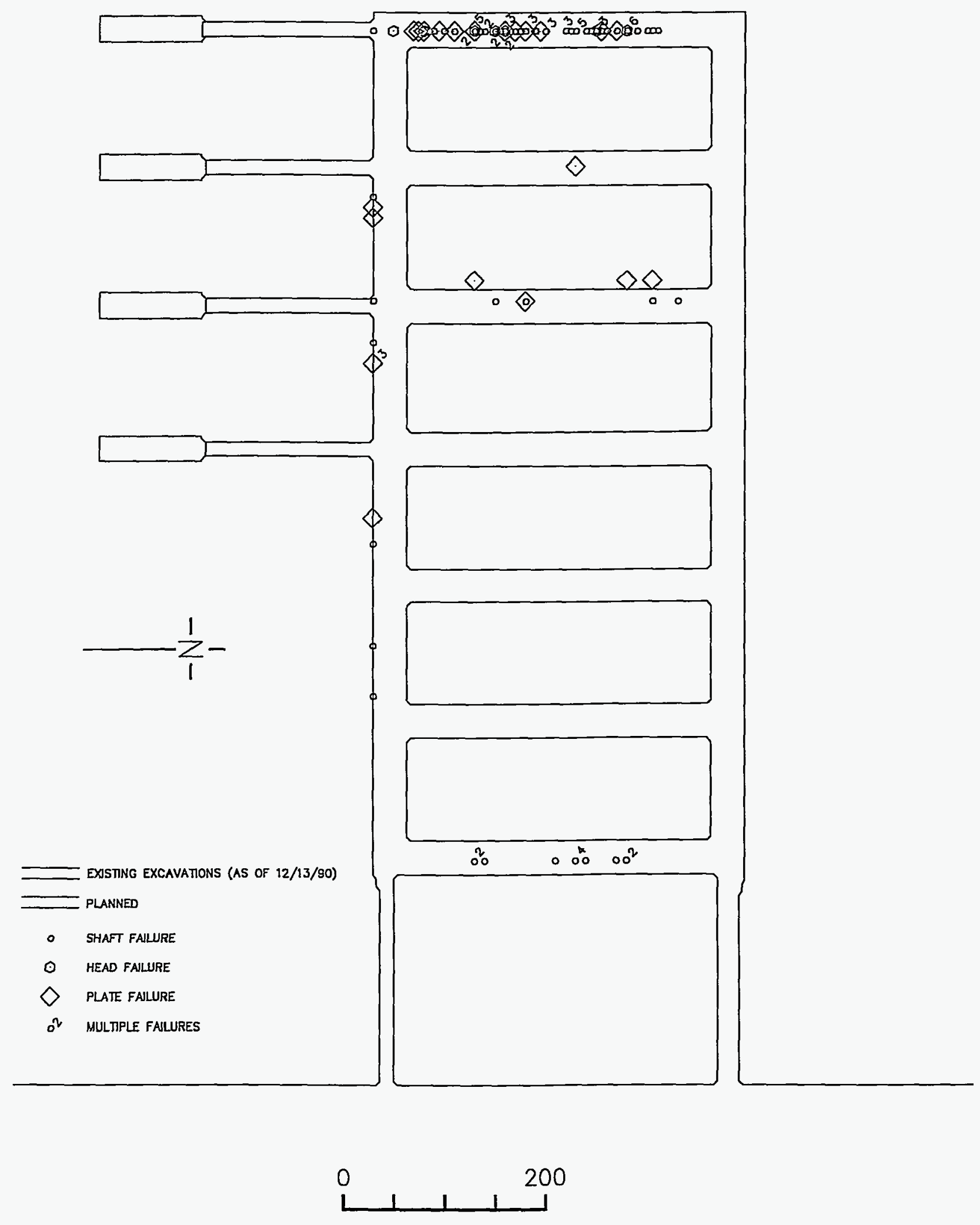

Figure 9c. Approximate location of threaded rebar failure in panel 1 for 1997. Maleki Technologies Inc. 


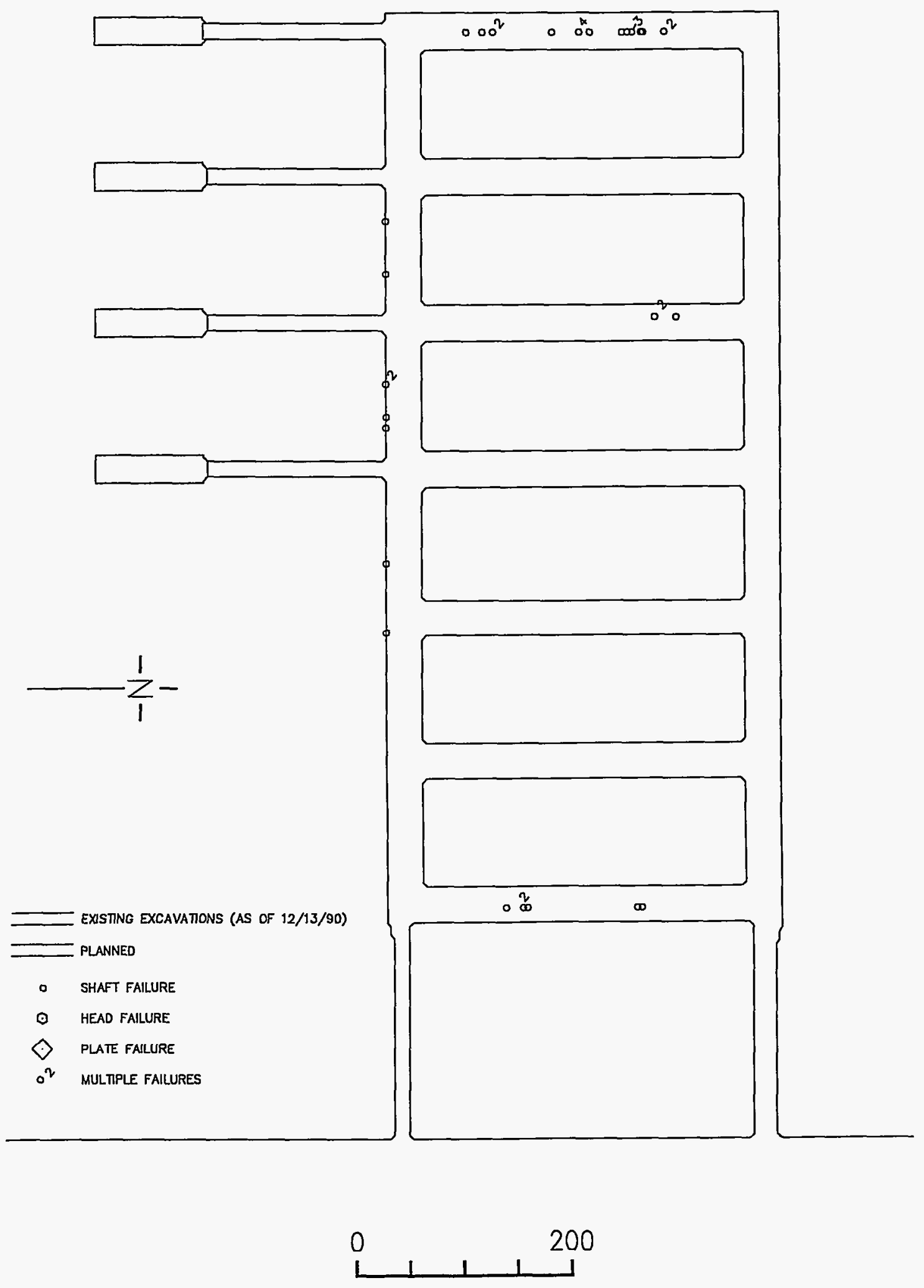

Figure 9d. Approximate location of threaded rebar failure in panel 1 for 1998. Maleki Technologies Inc. 


\section{Panel 1}

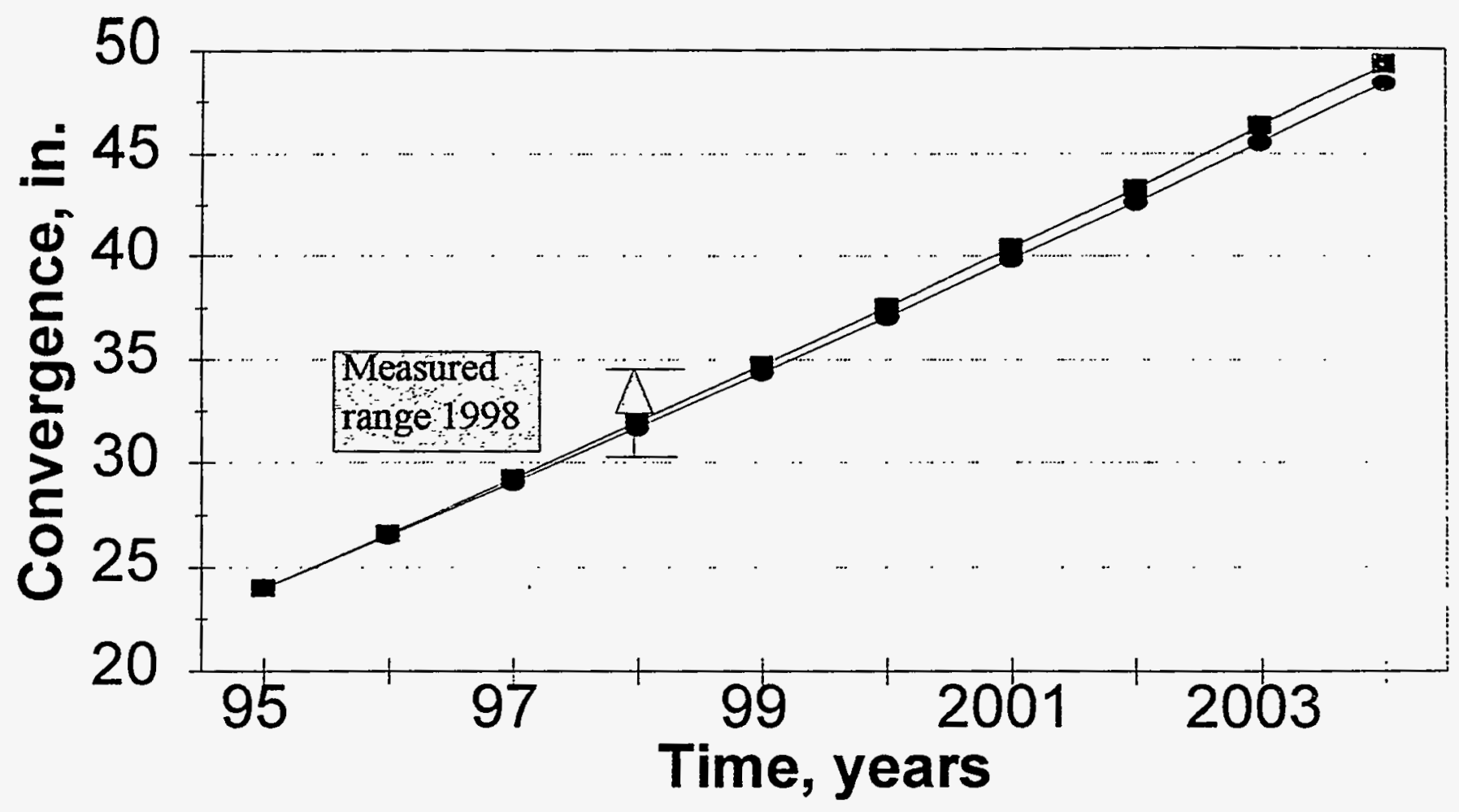

- Room 1 -Room 7

Figure 10 - Estimated and measured total convergence for rooms of Panel 1. 


\section{ATTACHMENT A}

Photographs of Roof and Rib Conditions in Panel 1 
South 1950 Access Drift 


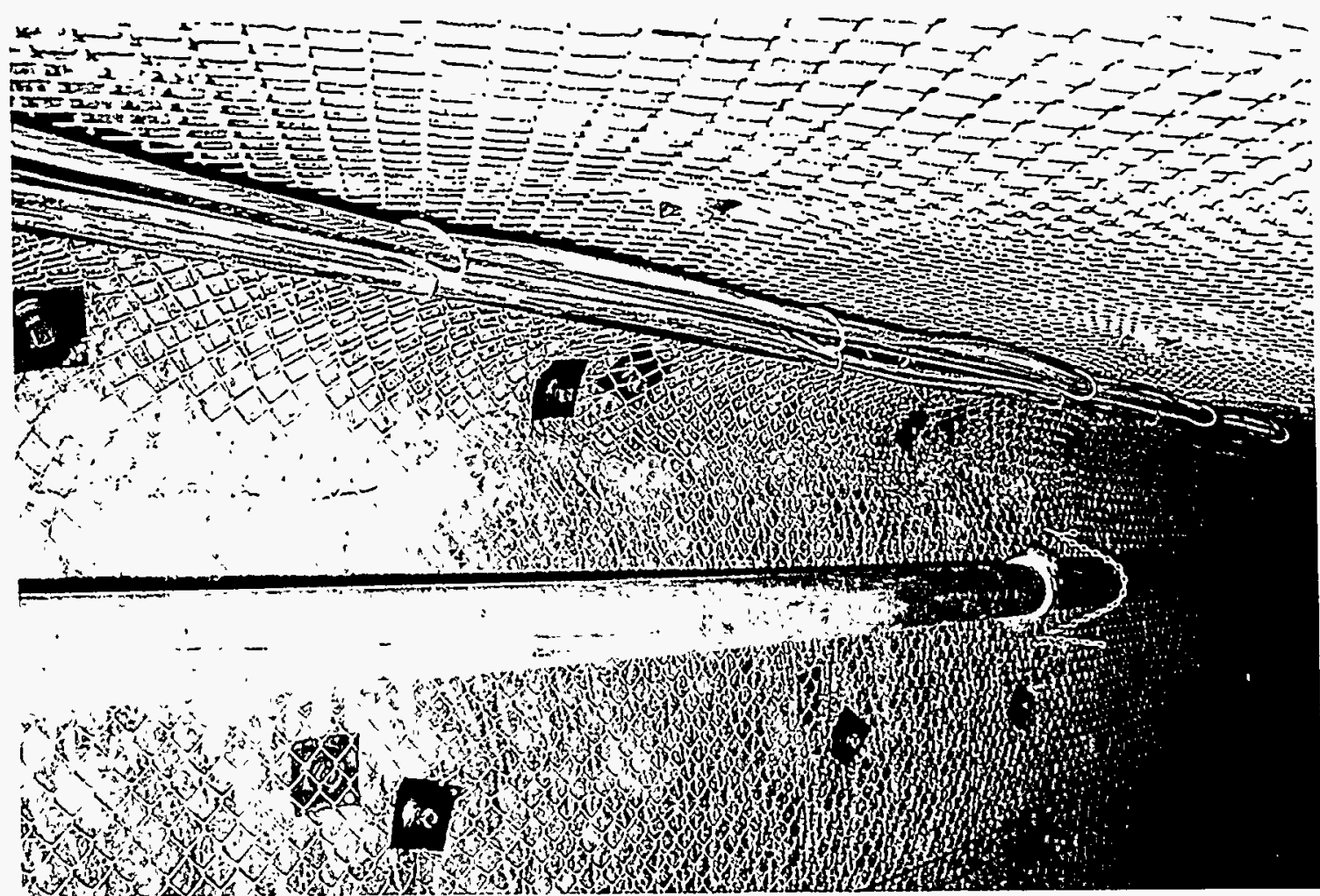


Rooms 1 to 7 


\section{MALEKI TECHNOLOGIES, INC.}
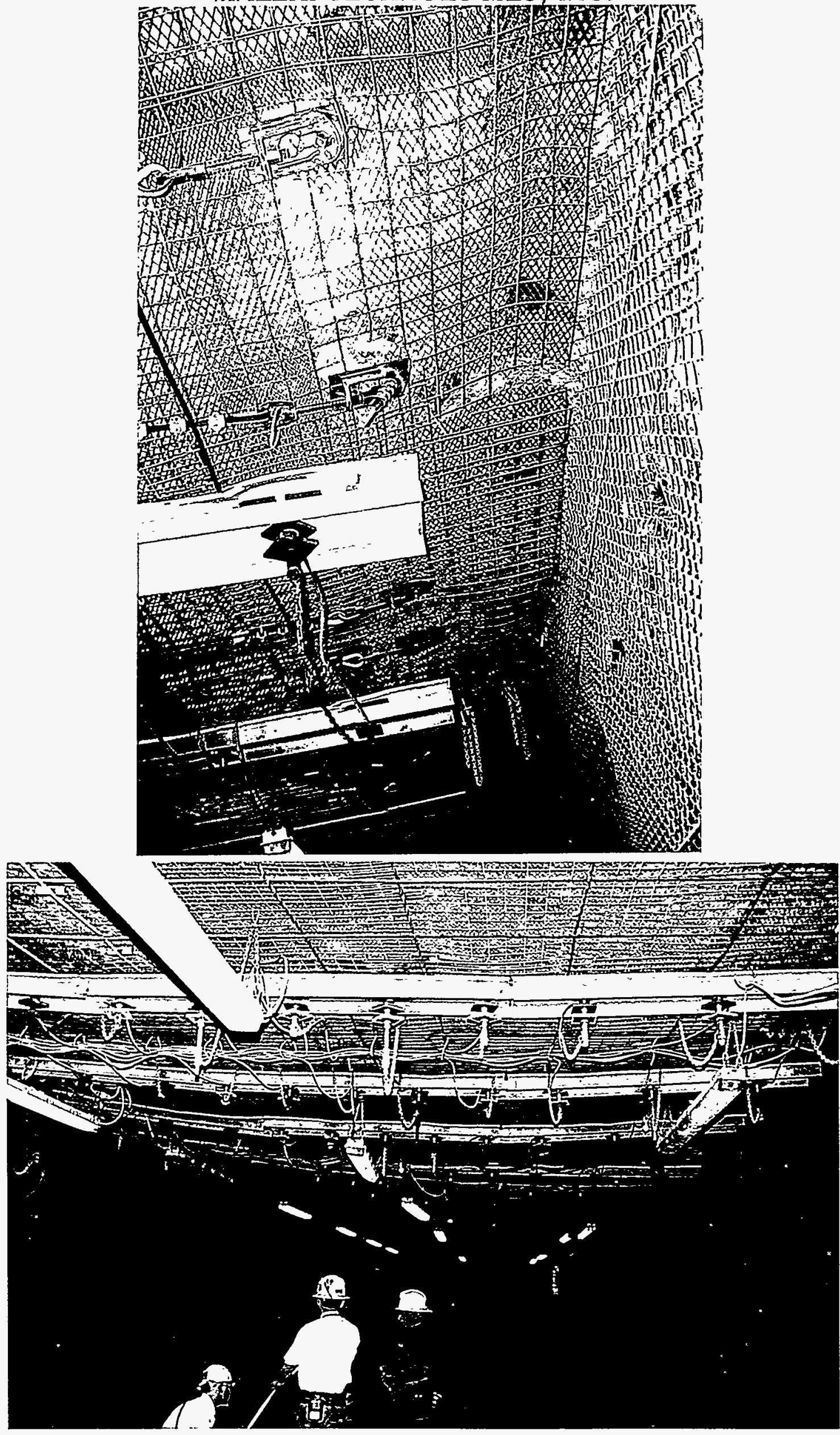


\section{MALEKI TECHNOLOGIES, INC.}
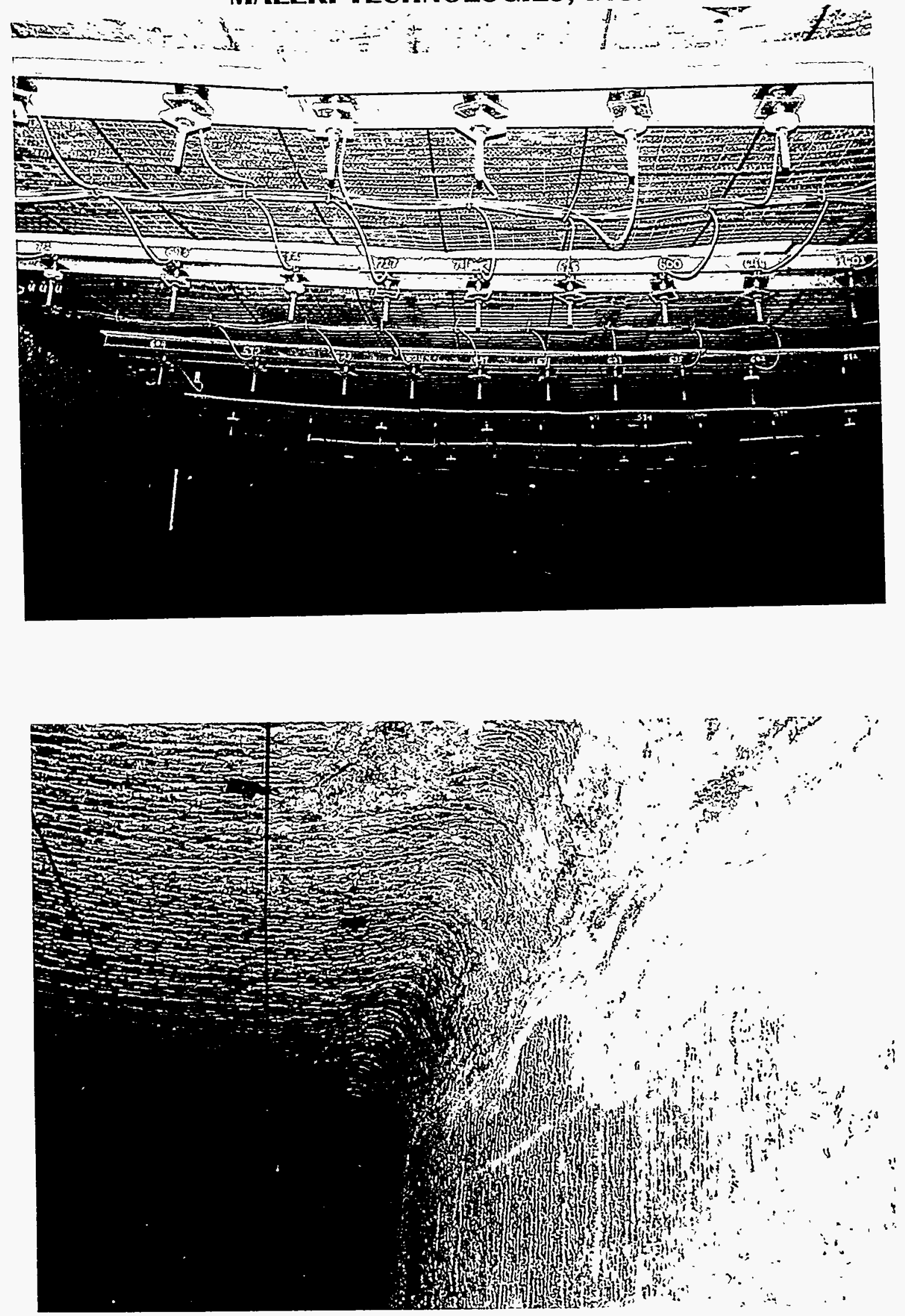


\section{MALEKI TECHNOLOGIES, INC.}
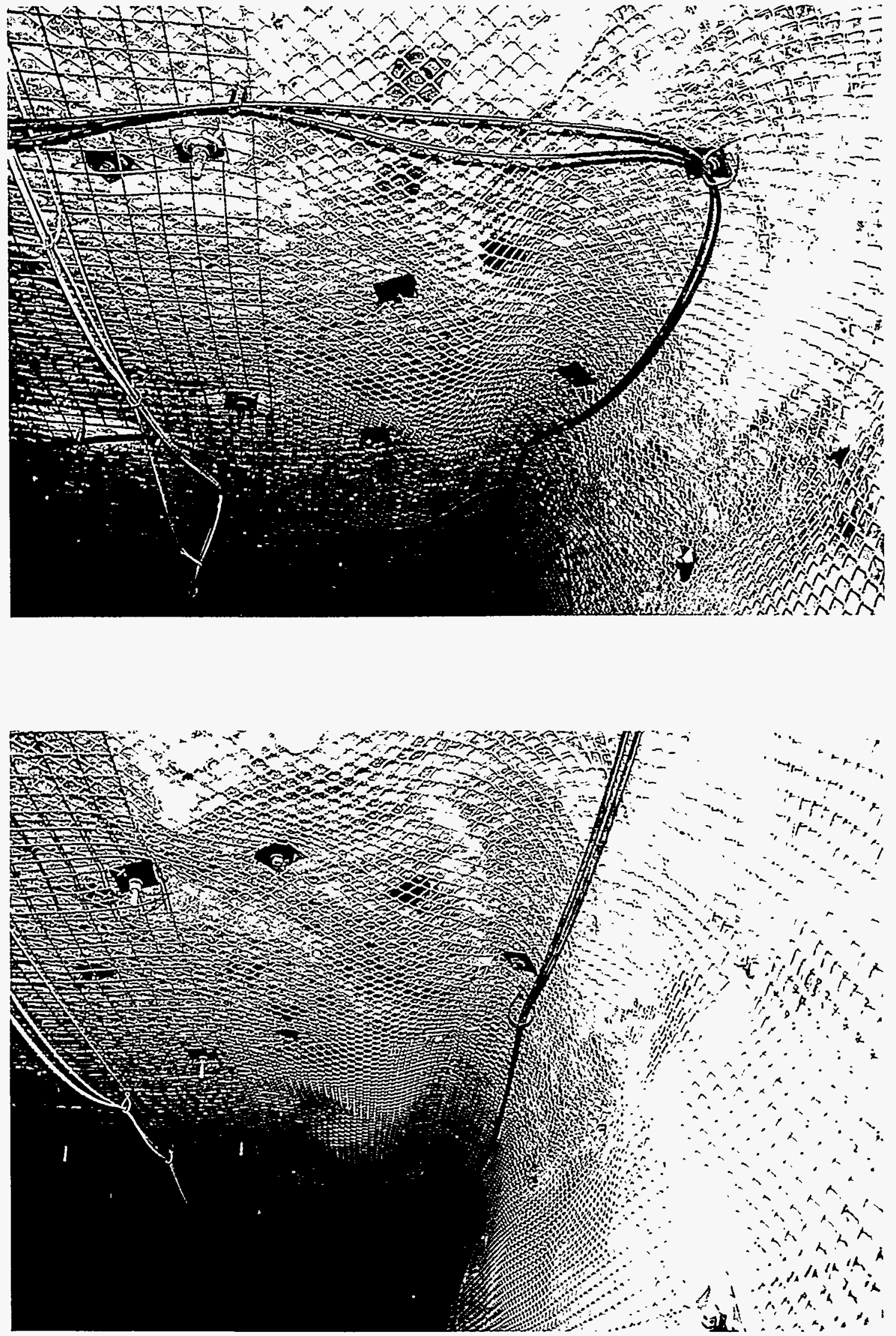
MALEKI TECHNOLOGIES, INC.
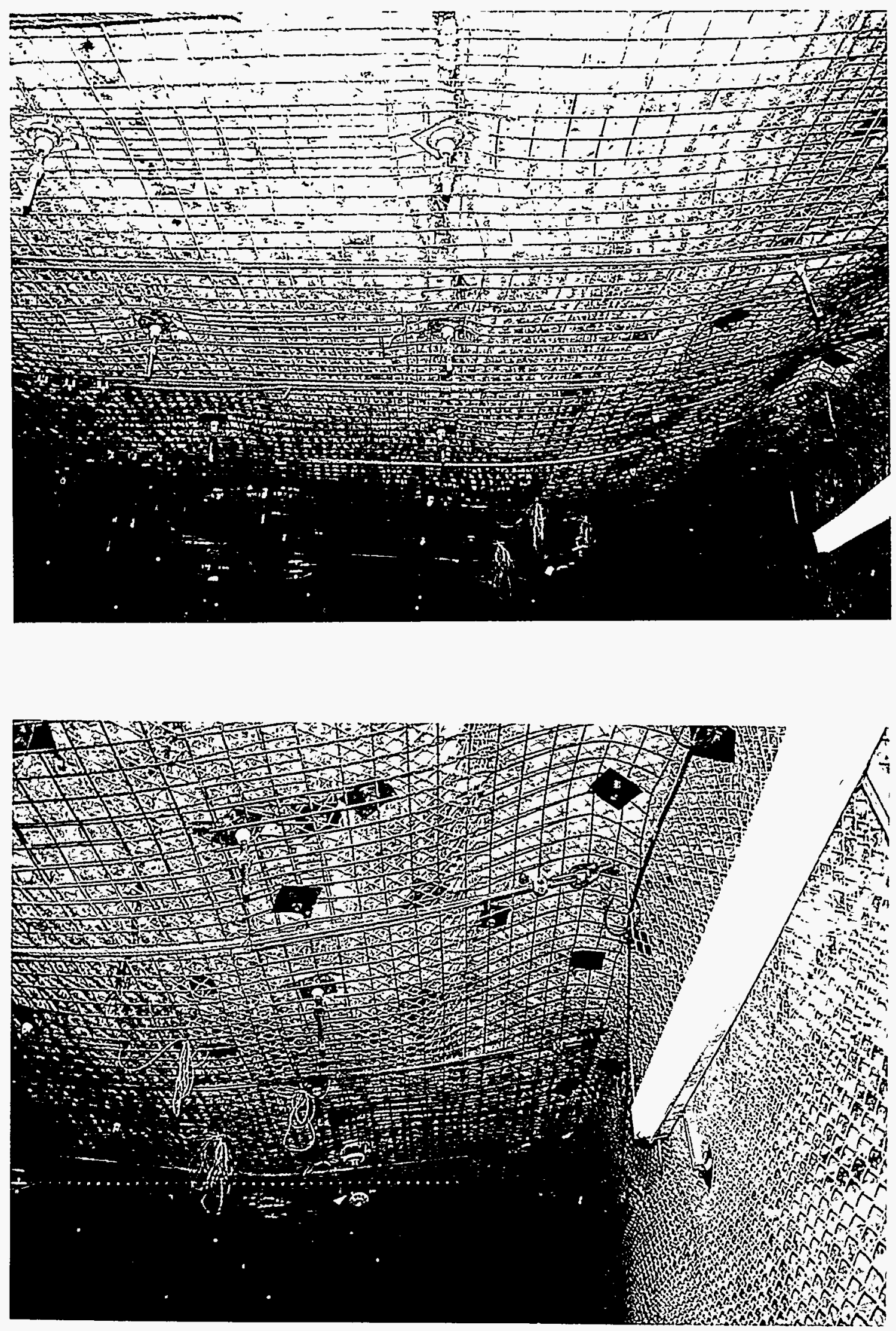


\section{MALEKI TECHNOLOGIES, INC.}
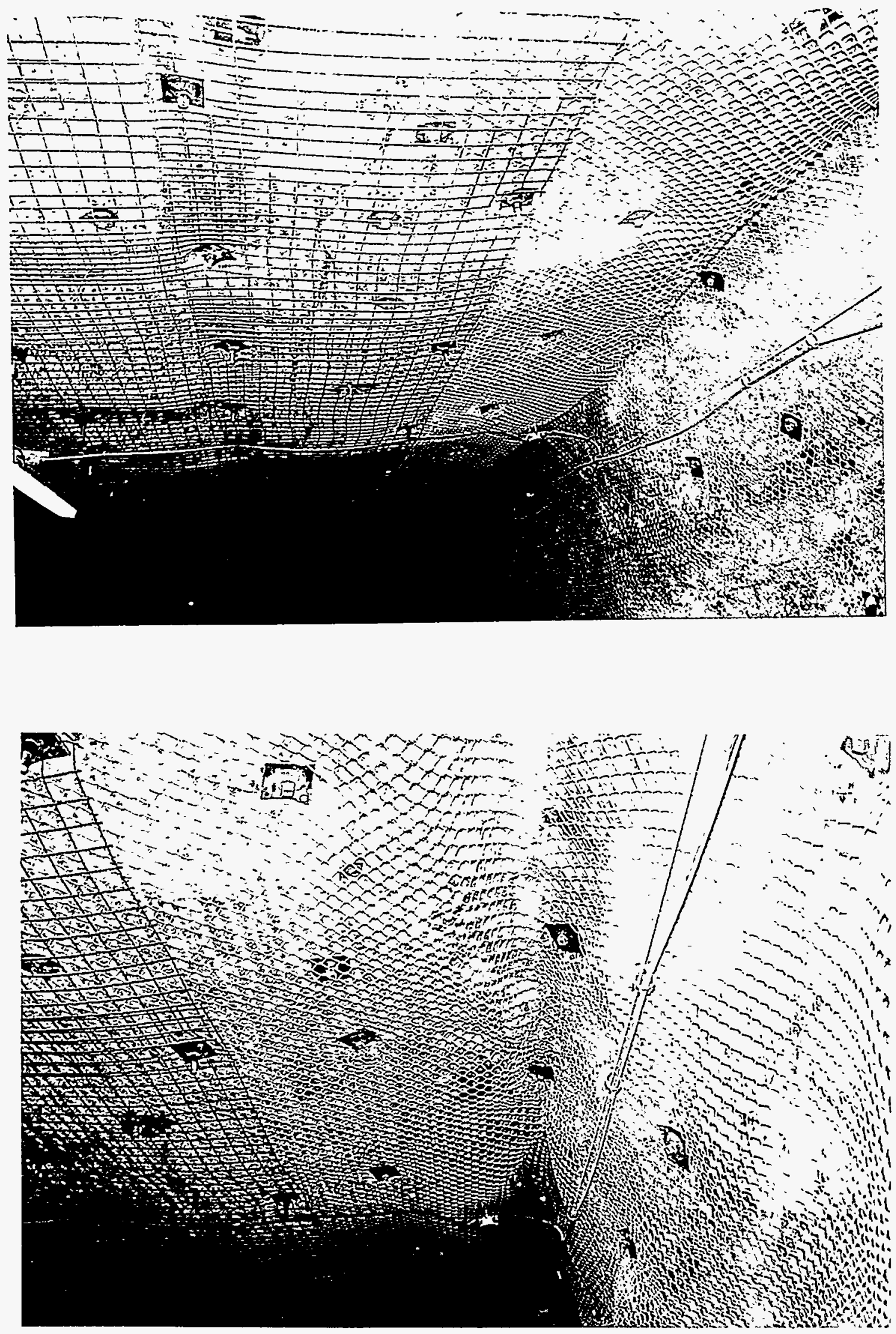
MALEKI TECHNOLOGIES, INC.
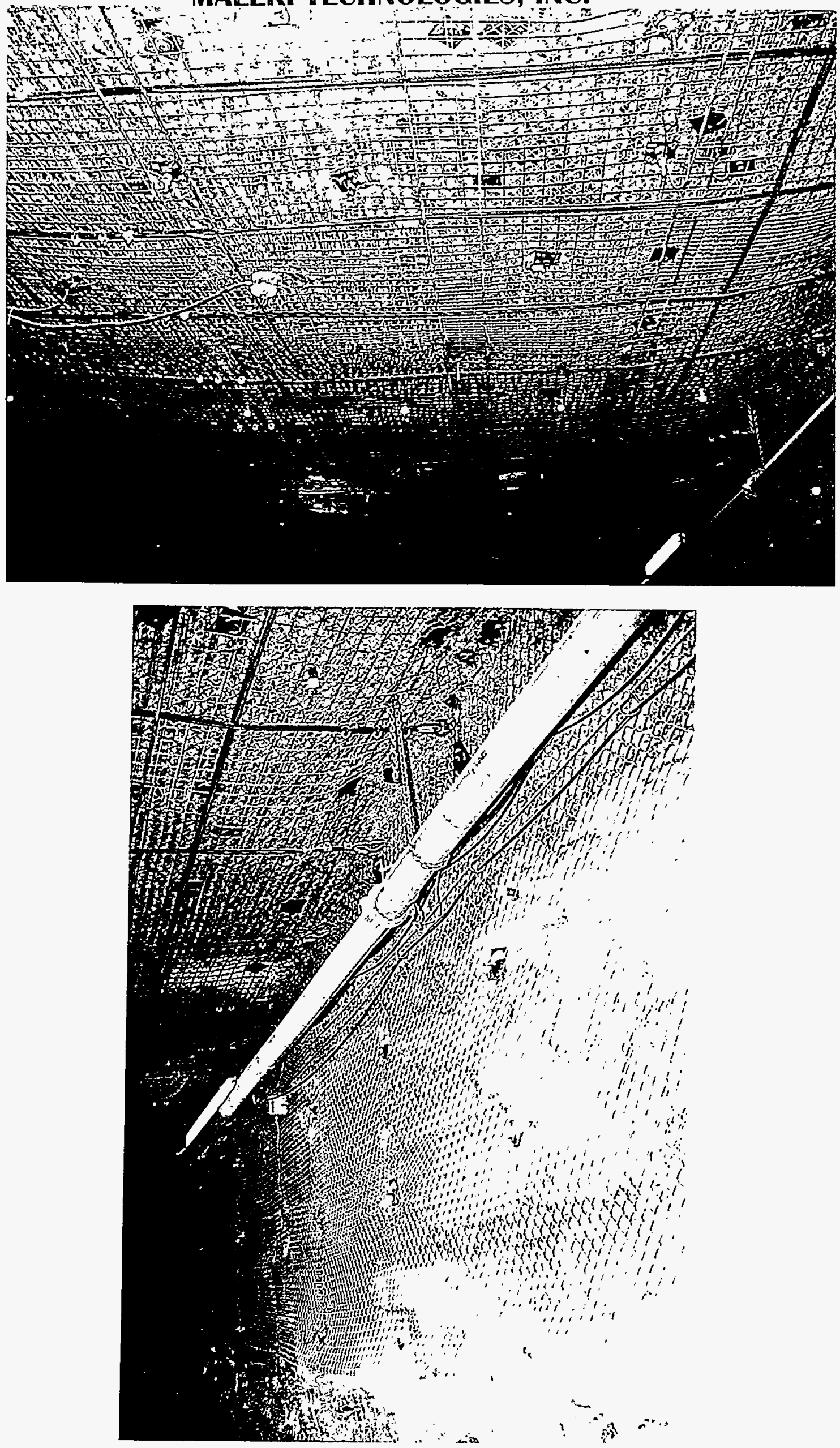
South 1600 Access Drift 
MALEKI TECHNOLOGIES. INC.
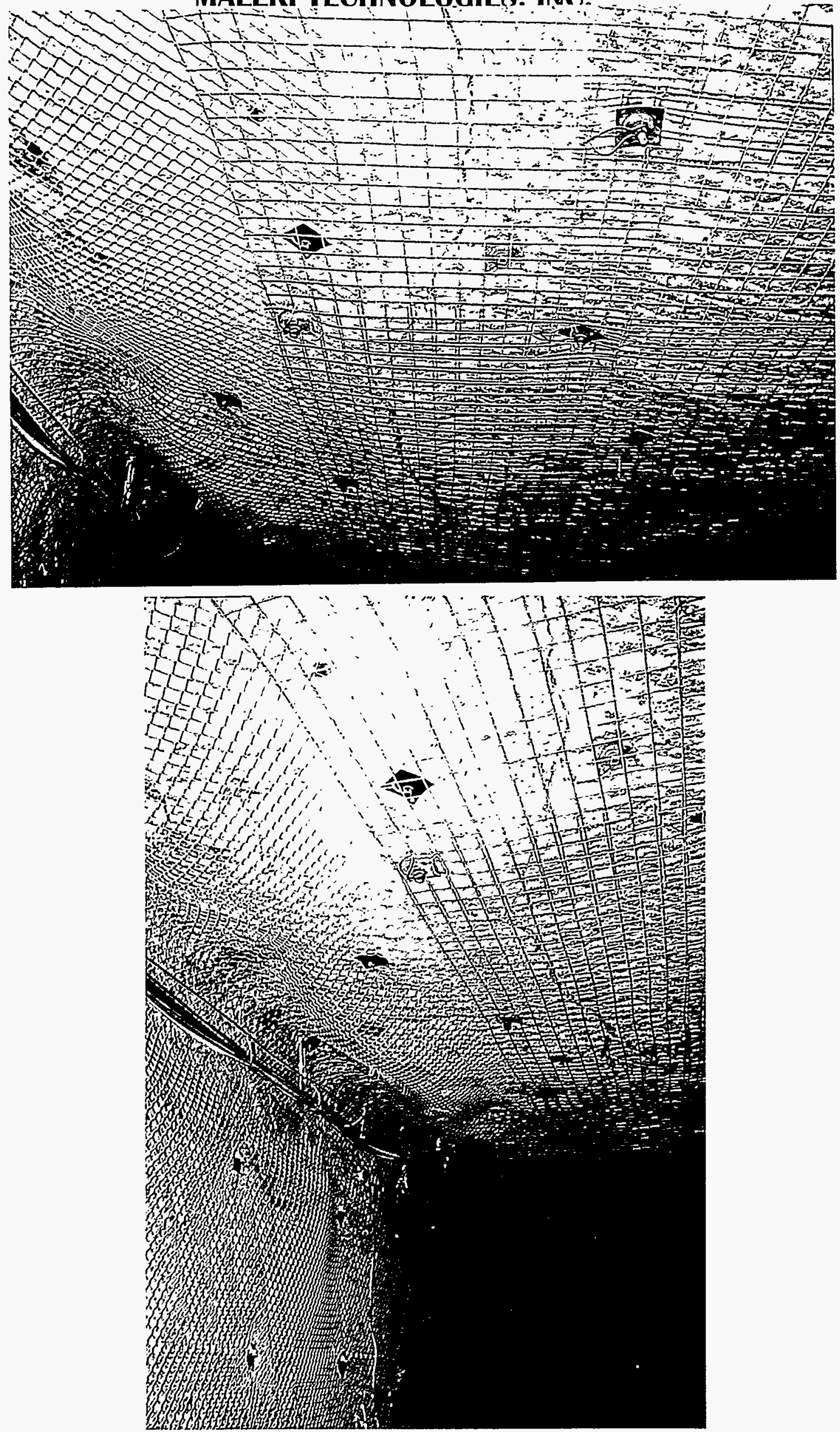


\section{MALEKI TECHNOLOGIES, INC.}
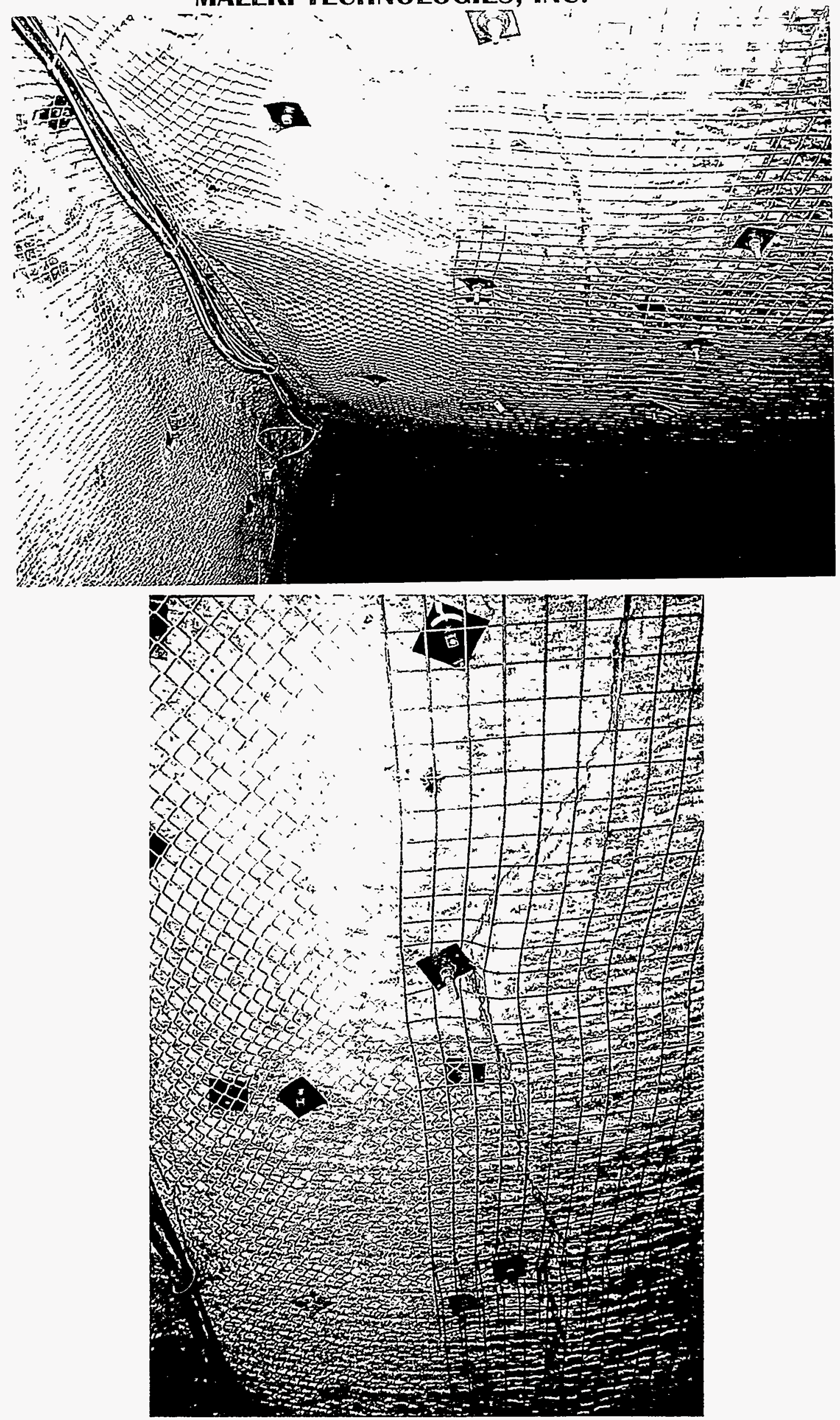


\section{MALEKI TECHNOLOGIES, INC.}
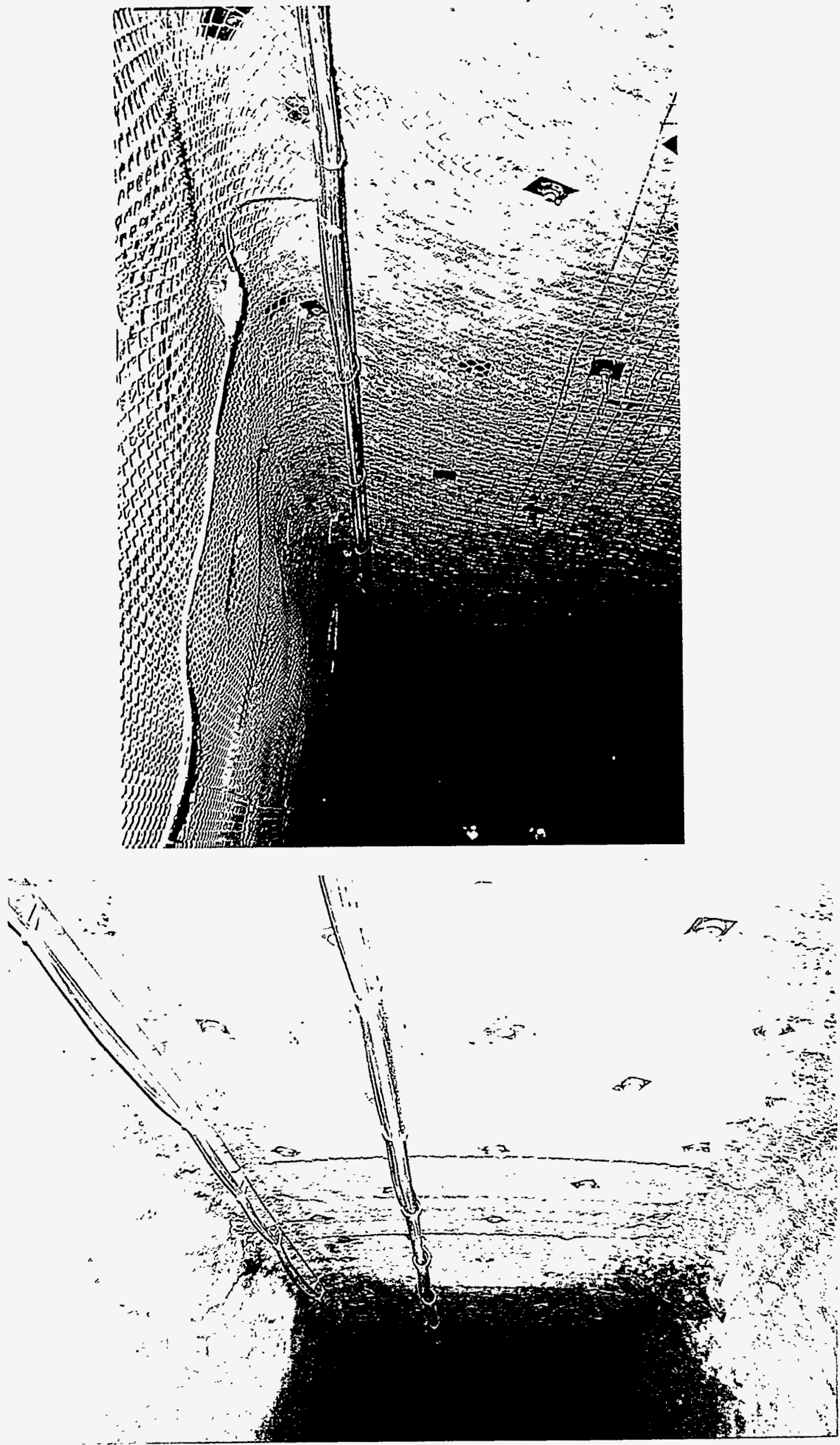


\section{LIST OF EEG REPORTS}




\section{LIST OF EEG REPORTS}

EEG-1 Goad, Donna, A Compilation of Site Selection Criteria Considerations and Concerns Appearing in the Literature on the Deep Disposal of Radioactive Wastes, June 1979.

EEG-2 Review Comments on Geological Characterization Report, Waste Isolation Pilot Plant (WIPP) Site, Southeastern New Mexico SAND 78-1596, Volumes I and II, December 1978.

EEG-3 Neill, Robert H., James K. Channell, Carla Wofsy and Moses A. Greenfield, Radiological Health Review of the Draft Environmental Impact Statement (DOE/EIS-0026-D) Waste Isolation Pilot Plant. U.S. Department of Energy, August 1979.

EEG-4 Little, Marshall S., Review Comments on the Report of the Steering Committee on Waste Acceptance Criteria for the Waste Isolation Pilot Plant, February 1980.

EEG-5 Channell, James K., Calculated Radiation Doses From Deposition of Material Released in Hypothetical Transportation Accidents Involving WIPP-Related Radioactive Wastes, November 1980.

EEG-6 Geotechnical Considerations for Radiological Hazard Assessment of WIPP. A Report of a Meeting Held on January 17-18, 1980, April 1980.

EEG-7 Chaturvedi, Lokesh, WIPP Site and Vicinity Geological Field Trip. A Report of a Field Trip to the Proposed Waste Isolation Pilot Plant Project in Southeastern. New Mexico, June 16 to 18,1980 . November 1980.

EEG-8 Wofsy, Carla, The Significance of Certain Rustler Aquifer Parameters for Predicting Long-Term Radiation Doses from WIPP, September 1980.

EEG-9 Spiegler, Peter, An Approach to Calculating Upper Bounds on Maximum Individual Doses From the Use of Contaminated Well Water Following a WIPP Repository Breach, September 1981.

EEG-10 Radiological Health Review of the Final Environmental Impact Statement (DOE/EIS-0026) Waste Isolation Pilot Plant. U. S. Department of Energy, January 1981.

EEG-11 Channell, James K., Calculated Radiation Doses From Radionuclides Brought to the Surface if Future Drilling Intercepts the WIPP Repository and Pressurized Brine, January 1982.

EEG-12 Little, Marshall S., Potential Release Scenario and Radiological Consequence Evaluation of Mineral Resources at WIPP, May 1982.

EEG-13 Spiegler, Peter., Analysis of the Potential Formation of a Breccia Chimney Beneath the WIPP Repository, May, 1982.

EEG-14 Not published.

EEG-15 Bard, Stephen T., Estimated Radiation Doses Resulting if an Exploratory Borehole Penetrates a Pressurized Brine Reservoir Assumed to Exist Below the WIPP Repository Horizon. March 1982.

EEG-16 Radionuclide Release. Transport and Consequence Modeling for WIPP. A Report of a Workshop Held on September 16-17, 1981, February 1982.

EEG-17 Spiegler, Peter, Hydrologic Analyses of Two Brine Encounters in the Vicinity of the Waste Isolation Pilot Plant (WIPP) Site, December 1982. 


\section{LIST OF EEG REPORTS (continued)}

EEG-55 Silva, Matthew K., Implications of the Presence of Petroleum Resources on the Integrity of the WIPP June 1994.

EEG-56 Silva, Matthew K. and Robert H. Neill, Unresolved Issues for the Disposal of Remote-Handled Transuranic Waste in the Waste Isolation Pilot Plant, September 1994.

EEG-57 Lee, William W.-L., Lokesh Chaturvedi, Matthew K. Silva, Ruth Weiner and Robert H. Neill, An Appraisal of the 1992 Preliminary Performance Assessment for the Waste Isolation Pilot Plant, September 1994.

EEG-58 Kenney, Jim W., Paula S. Downes, Donald H. Gray and Sally C. Ballard, Radionuclide Baseline in Soil Near Project Gnome and the Waste Isolation Pilot Plant, July 1995.

EEG-59 Greenfield, Moses A. and Thomas J. Sargent, An Analysis of the Annual Probability of Failure of the Waste Hoist Brake System at the Waste Isolation Pilot Plant (WIPP), November 1995.

EEG-60 Bartlett, William T. and Ben A. Walker, The Influence of Salt Aerosol on Alpha Radiation Detection by WIPP Continuous Air Monitors, January 1996.

EEG-61 Neill, Robert H., Lokesh Chaturvedi, William W.-L. Lee, Thomas M. Clemo, Matthew K. Silva, Jim W. Kenney, William T. Bartlett and Ben A. Walker, Review of the WIPP Draft Application to Show Compliance with EPA Transuranic Waste Disposal Standards, March 1996.

EEG-62 Silva, Matthew K., Fluid Injection for Salt Water Disposal and Enhanced Oil Recovery as a Potential Problem for the WIPP: Proceedings of a June 1995 Workshop and Analysis, August 1996.

EEG-63 Maleki, Hamid and Lokesh Chaturvedi, Stability Evaluation of the E140 Drift and Panel 1 Rooms at WIPP, August 1996.

EEG-64 Neill, Robert H., James K. Channell and Peter Spiegler, Review of the Draft Supplement to the Environmental Impact Statement DOE/EIS-0026-S-2, April 1997.

EEG-65 Greenfield, Moses A. and Thomas J. Sargent, Probability of Failure of the Waste Hoist Brake System at the Waste Isolation Pilot Plant (WIPP) January 1998.

EEG-66 Channell, James K. and Robert H. Neill, Individual Radiation Doses from Transuranic Waste Brought to the Surface by Human Intrusion at the WIPP, February 1998.

EEG-67 Kenney, Jim W., Donald H. Gray and Sally C. Ballard, Preoperational Radiation Surveillance of the WIPP Project by EEG During 1993 through 1995, March 1998.

EEG-68 Neill, Robert H., Lokesh Chaturvedi, Dale Rucker, Matthew Silva, Ben A. Walker, James K. Channell, and Thomas M. Clemo, Evaluation of the WIPP Project's Compliance with the EPA Radiation Protection Standards for Disposal of Transuranic Waste, March 1998.

EEG-69 Rucker, Dale, Sensitivity Analysis of Performance Parameters Used in Modeling the Waste Isolation Pilot Plant, May 1998.

EEG-70 Bartlett, William T. and Jim W. Kenney, EEG Observations of the March 1998 WIPP Operational Readiness Review Audit, May 1998.

EEG-71 Maleki, Hamid, Mine Stability Evaluation of Panel 1 During Waste Emplacement Operations at WIPP July 1998. 


\section{LIST OF EEG REPORTS}

EEG-1 Goad, Donna, A Compilation of Site Selection Criteria Considerations and Concerns Appearing in the Literature on the Deep Disposal of Radioactive Wastes, June 1979.

EEG-2 Review Comments on Geological Characterization Report. Waste Isolation Pilot Plant (WIPP) Site, Southeastern New Mexico SAND 78-1596, Volumes I and II, December 1978.

EEG-3 Neill, Robert H., James K. Channell, Carla Wofsy and Moses A. Greenfield, Radiological Health Review of the Draft Environmental Impact Statement (DOE/EIS-0026-D) Waste Isolation Pilot Plant, U. S. Department of Energy, August 1979.

EEG-4 Little, Marshall S., Review Comments on the Report of the Steering_Committee on Waste Acceptance Criteria for the Waste Isolation Pilot Plant, February 1980.

EEG-5 Channell, James K., Calculated Radiation Doses From Deposition of Material Released in Hypothetical Transportation Accidents Involving WIPP-Related Radioactive Wastes, November 1980.

EEG-6 Geotechnical Considerations for Radiological Hazard Assessment of WIPP. A Report of a Meeting Held on January 17-18, 1980, April 1980.

EEG-7 Chaturvedi, Lokesh, WIPP Site and Vicinity Geological Field Trip. A Report of a Field Trip to the Proposed Waste Isolation Pilot Plant Project in Southeastern New Mexico, June 16 to 18, 1980 November 1980.

EEG-8 Wofsy, Carla, The Significance of Certain Rustler Aquifer Parameters for Predicting Long-Term Radiation Doses from WIPP, September 1980.

EEG-9 Spiegler, Peter, An Approach to Calculating Upper Bounds on Maximum Individual Doses From the Use of Contaminated Well Water Following a WIPP Repository Breach, September 1981.

EEG-10 Radiological Health Review of the Final Environmental Impact Statement (DOE/EIS-0026) Waste Isolation Pilot Plant, U. S. Department of Energy January 1981.

EEG-11 Channell, James K., Calculated Radiation Doses From Radionuclides Brought to the Surface if Future Drilling Intercepts the WIPP Repository and Pressurized Brine January 1982.

EEG-12 Little, Marshall S., Potential Release Scenario and Radiological Consequence Evaluation of Mineral Resources at WIPP, May 1982.

EEG-13 Spiegler, Peter., Analysis of the Potential Formation of a Breccia Chimney Beneath the WIPP Repository, May, 1982.

EEG-14 Not published.

EEG-15 Bard, Stephen T., Estimated Radiation Doses Resulting if an Exploratory Borehole Penetrates a Pressurized Brine Reservoir Assumed to Exist Below the WIPP Repository Horizon, March 1982.

EEG-16 Radionuclide Release, Transport and Consequence Modeling for WIPP. A Report of a Workshop Held on September 16-17, 1981, February 1982.

EEG-17 Spiegler, Peter, Hydrologic Analyses of Two Brine Encounters in the Vicinity of the Waste Isolation Pilot Plant (WIPP) Site, December 1982. 


\section{LIST OF EEG REPORTS (continued)}

EEG-18 Spiegler, Peter, Origin of the Brines Near WIPP from the Drill Holes ERDA-6 and WIPP-12 Based on Stable Isotope Concentration of Hydrogen and Oxygen, March 1983.

EEG-19 Channell, James K., Review Comments on Environmental Analysis Cost Reduction Proposals WIPP/DOE-136) July 1982, November 1982.

EEG-20 Baca, Thomas E., An Evaluation of the Non-radiological Environmental Problems Relating to the WIPP, February 1983.

EEG-21 Faith, Stuart, Peter Spiegler and Kenneth Rehfeldt, The Geochemistry of Two Pressurized Brines From the Castile Formation in the Vicinity of the Waste Isolation Pilot Plant (WIPP) Site, April 1983.

EEG-22 EEG Review Comments on the Geotechnical Reports Provided by DOE to EEG Under the Stipulated Agreement Through March 1, 1983, April 1983.

EEG-23 Neill, Robert H., James K. Channell, Lokesh Chaturvedi, Marshall S. Little, Kenneth Rehfeldt and Peter Spiegler, Evaluation of the Suitability of the WIPP Site, May 1983.

EEG-24 Neill, Robert H. and James K. Channell, Potential Problems From Shipment of High-Curie Content Contact-Handled Transuranic (CH-TRU) Waste to WIPP, August 1983.

EEG-25 Chaturvedi, Lokesh, Occurrence of Gases in the Salado Formation, March 1984.

EEG-26 Spiegler, Peter, Environmental Evaluation Group's Environmental Monitoring Program for WIPP, October 1984.

EEG-27 Rehfeldt, Kenneth, Sensitivity Analysis of Solute Transport in Fractures and Determination of Anisotropy Within the Culebra Dolomite, September 1984.

EEG-28 Knowles, H. B., Radiation Shielding in the Hot Cell Facility at the Waste Isolation Pilot Plant: A Review, November 1984.

EEG-29 Little, Marshall S., Evaluation of the Safety Analysis Report for the Waste Isolation Pilot Plant Project, May 1985.

EEG-30 Dougherty, Frank, Tenera Corporation, Evaluation of the Waste Isolation Pilot Plant Classification of Systems, Structures and Components, July 1985.

EEG-31 Ramey, Dan, Chemistry of the Rustler Fluids, July 1985.

EEG-32 Chaturvedi, Lokesh and James K. Channell, The Rustler Formation as a Transport Medium for Contaminated Groundwater, December 1985.

EEG-33 Channell, James K., John C. Rodgers and Robert H. Neill, Adequacy of TRUPACT-I Design for Transporting Contact-Handled Transuranic Wastes to WIPP June 1986.

EEG-34 Chaturvedi, Lokesh, (ed.), The Rustler Formation at the WIPP Site, January 1987.

EEG-35 Chapman, Jenny B., Stable Isotopes in Southeastern New Mexico Groundwater: Implications for Dating Recharge in the WIPP Area, October 1986.

EEG-36 Lowenstein, Tim K., Post Burial Alteration of the Permian Rustler Formation Evaporites, WIPP Site, New Mexico, April 1987. 


\section{LIST OF EEG REPORTS (continued)}

EEG-37 Rodgers, John C., Exhaust Stack Monitoring Issues at the Waste Isolation Pilot Plant November 1987.

EEG-38 Rodgers, John C., Jim W. Kenney, A Critical Assessment of Continuous Air Monitoring Systems At he Waste Isolation Pilot Plant, March 1988.

EEG-39 Chapman, Jenny B., Chemical and Radiochemical Characteristics of Groundwater in the Culebra Dolomite, Southeastern New Mexico, March 1988.

EEG-40 Review of the Final Safety Analysis Report (Draft). DOE Waste Isolation Pilot Plant May 1989.

EEG-41 Review of the Draft Supplement Environmental Impact Statement, DOE Waste Isolation Pilot Plant, July 1989.

EEG-42 Chaturvedi, Lokesh, Evaluation of the DOE Plans for Radioactive Experiments and Operational Demonstration at WIPP September, 1989.

EEG-43 Kenney, Jim W., John C. Rodgers, Jenny B. Chapman and Kevin J. Shenk, Preoperational Radiation Surveillance of the WIPP Project by EEG, 1985-1988, January 1990.

EEG-44 Greenfield, Moses A., Probabilities of a Catastrophic Waste Hoist Accident at the Waste Isolation Pilot Plant, January 1990.

EEG-45 Silva, Matthew K., Preliminary Investigation into the Explosion Potential of Volatile Organic Compounds in WIPP CH-TRU Waste, June 1990.

EEG-46 Gallegos, Anthony, and James K. Channell, Risk Analysis of the Transport of Contact Handled Transuranic (CH-TRU) Wastes to WIPP Along Selected Highway Routes in New Mexico Using RADTRAN IV, August 1990.

EEG-47 Kenney, Jim W. and Sally C. Ballard, Preoperational Radiation Surveillance of the WIPP Project by EEG During 1989, December 1990.

EEG-48 Silva, Matthew K., An Assessment of the Flammability and Explosion Potential of Transuranic Waste, June 1991.

EEG-49 Kenney, Jim W., Preoperational Radiation Surveillance of the WIPP Project by EEG During 1990, November 1991.

EEG-50 Silva, Matthew K. and James K. Channell, Implications of Oil and Gas Leases at the WIPP on Compliance with EPA TRU Waste Disposal Standards, June 1992.

EEG-51 Kenney, Jim W., Preoperational Radiation Surveillance of the WIPP Project by EEG During 1991, October 1992.

EEG-52 Bartlett, William T., An Evaluation of Air Effluent and Workplace Radioactivity Monitoring at the Waste Isolation Pilot Plant, February 1993.

EEG-53 Greenfield, Moses A., and Thomas J. Sargent, A Probabilistic Analysis of a Catastrophic Transuranic Waste Hoist Accident at the WIPP, June 1993.

EEG-54 Kenney, Jim W., Preoperational Radiation Surveillance of the WIPP Project by EEG During 1992 February 1994. 


\section{LIST OF EEG REPORTS (continued)}

EEG-55 Silva, Matthew K., Implications of the Presence of Petroleum Resources on the Integrity of the WIPP June 1994.

EEG-56 Silva, Matthew K. and Robert H. Neill, Unresolved Issues for the Disposal of Remote-Handled Transuranic Waste in the Waste Isolation Pilot Plant, September 1994.

EEG-57 Lee, William W.-L., Lokesh Chaturvedi, Matthew K. Silva, Ruth Weiner and Robert H. Neill, An Appraisal of the 1992 Preliminary Performance Assessment for the Waste Isolation Pilot Plant, September 1994.

EEG-58 Kenney, Jim W., Paula S. Downes, Donald H. Gray and Sally C. Ballard, Radionuclide Baseline in Soil Near Project Gnome and the Waste Isolation Pilot Plant, July 1995.

EEG-59 Greenfield, Moses A. and Thomas J. Sargent, An Analysis of the Annual Probability of Failure of the Waste Hoist Brake System at the Waste Isolation Pilot Plant (WIPP), November 1995.

EEG-60 Bartlett, William T. and Ben A. Walker, The Influence of Salt Aerosol on Alpha Radiation Detection by WIPP Continuous Air Monitors, January 1996.

EEG-61 Neill, Robert H., Lokesh Chaturvedi, William W.-L. Lee, Thomas M. Clemo, Matthew K. Silva, Jim W. Kenney, William T. Bartlett and Ben A. Walker, Review of the WIPP Draft Application to Show Compliance with EPA Transuranic Waste Disposal Standards, March 1996.

EEG-62 Silva, Matthew K., Fluid Injection for Salt Water Disposal and Enhanced Oil Recovery as a Potential Problem for the WIPP: Proceedings of a June 1995 Workshop and Analysis, August 1996.

EEG-63 Maleki, Hamid and Lokesh Chaturvedi, Stability Evaluation of the E140 Drift and Panel 1 Rooms at WIPP, August 1996.

EEG-64 Neill, Robert H., James K. Channell and Peter Spiegler, Review of the Draft Supplement to the Environmental Impact Statement DOE/EIS-0026-S-2, April 1997.

EEG-65 Greenfield, Moses A. and Thomas J. Sargent, Probability of Failure of the Waste Hoist Brake System at the Waste Isolation Pilot Plant (WIPP), January 1998.

EEG-66 Channell, James K. and Robert H. Neill, Individual Radiation Doses from Transuranic Waste Brought to the Surface by Human Intrusion at the WIPP, February 1998.

EEG-67 Kenney, Jim W., Donald H. Gray and Sally C. Ballard, Preoperational Radiation Surveillance of the WTPP Project by EEG During 1993 through 1995, March 1998.

EEG-68 Neill, Robert H., Lokesh Chaturvedi, Dale Rucker, Matthew Silva, Ben A. Walker, James K. Channell, and Thomas M. Clemo, Evaluation of the WIPP Project's Compliance with the EPA Radiation Protection Standards for Disposal of Transuranic Waste, March 1998.

EEG-69 Rucker, Dale, Sensitivity Analysis of Performance Parameters Used in Modeling the Waste Isolation Pilot Plant, May 1998.

EEG-70 Bartlett, William T. and Jim W. Kenney, EEG Observations of the March 1998 WIPP Operational Readiness Review Audit, May 1998.

EEG-71 Maleki, Hamid, Mine Stability Evaluation of Panel 1 During Waste Emplacement Operations at WIPP July 1998. 